\title{
The analysis of morphological, physiological and ecological traits that influence efficacy to the foliar-applied herbicide glyphosate
}

\author{
Kessiena L. Aya, B.Sc. (Honors)
}

A thesis submitted to the Faculty of Graduate Studies and Research in partial fulfillment of the requirements for the degree of

\author{
Masters of Science \\ Biology
}

Department of Biology

Faculty of Science

Carleton University

Ottawa, Ontario

(C) Kessiena L. Aya, 2010 


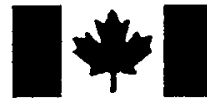

Library and Archives

Canada

Published Heritage

Branch

395 Wellington Street

Ottawa ON K1A ON4

Canada
Bibliothèque et

Archives Canada

Direction du

Patrimoine de l'édition

395 , rue Wellington

Ottawa ON K1A ON4

Canada
Your file Votre référence

ISBN: 978-0-494-81689-9

Our file Notre référence

ISBN: 978-0-494-81689-9
NOTICE:

The author has granted a nonexclusive license allowing Library and Archives Canada to reproduce, publish, archive, preserve, conserve, communicate to the public by telecommunication or on the Internet, loan, distribute and sell theses worldwide, for commercial or noncommercial purposes, in microform, paper, electronic and/or any other formats.

The author retains copyright ownership and moral rights in this thesis. Neither the thesis nor substantial extracts from it may be printed or otherwise reproduced without the author's permission.
AVIS:

L'auteur a accordé une licence non exclusive permettant à la Bibliothèque et Archives Canada de reproduire, publier, archiver, sauvegarder, conserver, transmettre au public par télécommunication ou par l'Internet, prêter, distribuer et vendre des thèses partout dans le monde, à des fins commerciales ou autres, sur support microforme, papier, électronique et/ou autres formats.

L'auteur conserve la propriété du droit d'auteur et des droits moraux qui protège cette thèse. $\mathrm{Ni}$ la thèse ni des extraits substantiels de celle-ci ne doivent être imprimés ou autrement reproduits sans son autorisation.
In compliance with the Canadian Privacy Act some supporting forms may have been removed from this thesis.

While these forms may be included in the document page count, their removal does not represent any loss of content from the thesis.
Conformément à la loi canadienne sur la protection de la vie privée, quelques formulaires secondaires ont été enlevés de cette thèse.

Bien que ces formulaires aient inclus dans la pagination, il n'y aura aucun contenu manquant.

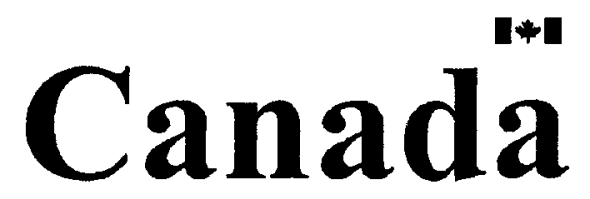




\begin{abstract}
The morphological, physiological and ecological traits of native and crop species were evaluated to assess the influence of plant traits on the efficacy of foliar applied herbicides. Traits observed included stomata parameters, trichome density, wax load and various leaf physiological traits. Overall, relative growth rate and the leaf area ratio were seen to be the best estimates for sensitivity, while stomata parameters were overall the least reliable predictor of herbicidal efficacy. Arabidopsis mutants with altered leaf traits were tested for the effect of separate traits on glyphosate resistance. Mutants with increased stomata or trichome densities (tmm1, sdd1, and bsh) showed significant increases in sensitivity to glyphosate, whereas mutants with reduced trichomes were more resistant (glabrous 1 and 3). The study demonstrated that although a complex relationship may exist between foliar-applied herbicides and efficacy, these traits still need to be considered for in the range of plant species used in phytotoxicity tests.
\end{abstract}




\section{ACKNOWLEDGEMENTS}

I would like to thank my supervisors Dr Celine Boutin and Dr Owen Rowland, for their guidance in all parts of this project. Thanks also to David Carpenter and Ian Pulsifer for their invaluable help. Lastly, thanks to my parents and family for putting up with me. 


\section{TABLE OF CONTENTS}

Abstract

. .1

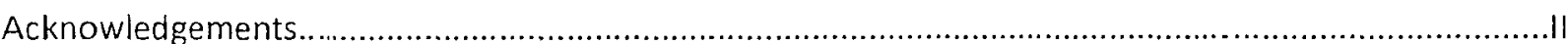

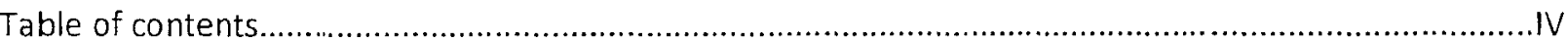

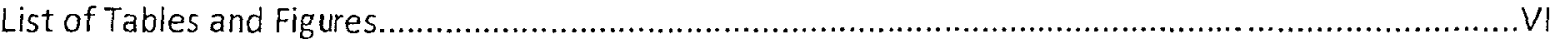

Appendix 1.1 Leaf characteristics of plant species used in this study .........................................51

Appendix 1.2 Wax, trichome and stomata characteristics of plant species used in this study............53

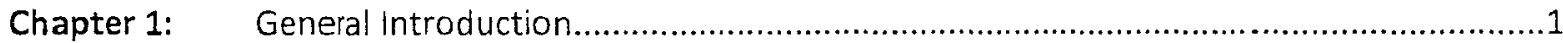

Chapter 2: Influence of morphological, physiological and ecological traits on the response of plants to foliar applied herbicides

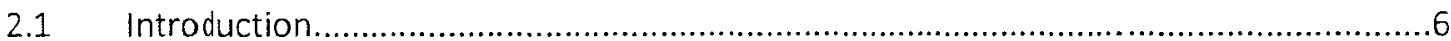

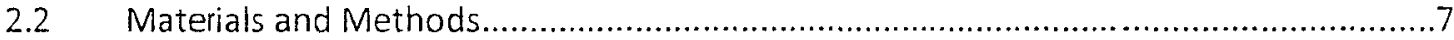

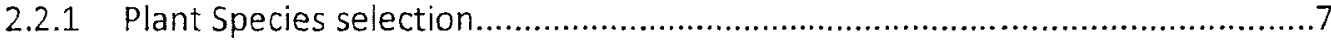

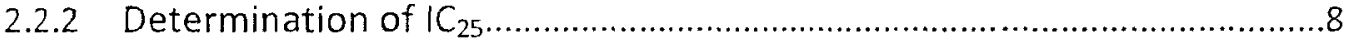

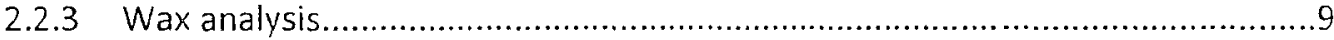

2.2.4 Physiological parameters under consideration..........................................10

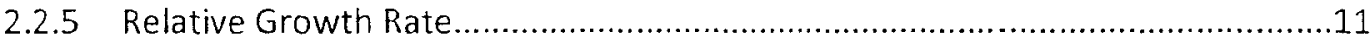

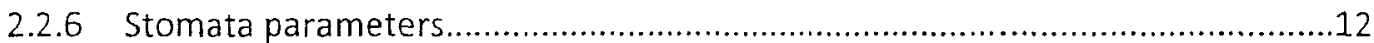

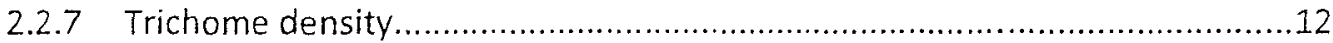

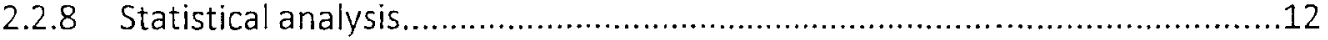

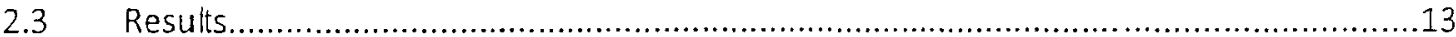




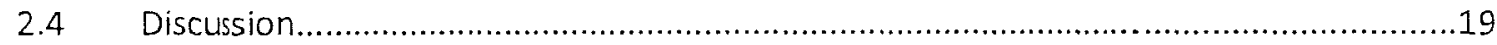

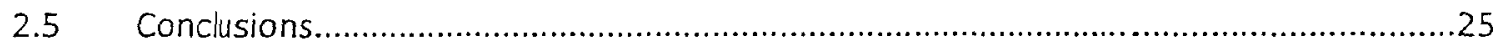

Chapter 3: Influence of morphological phenotypic traits on the efficacy of Arabidopsis mutants to foliarapplied herbicides

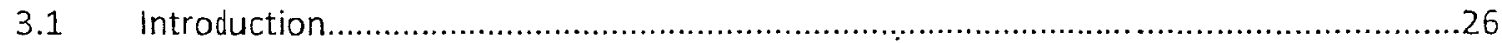

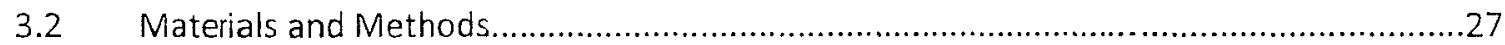

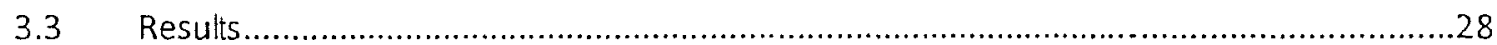

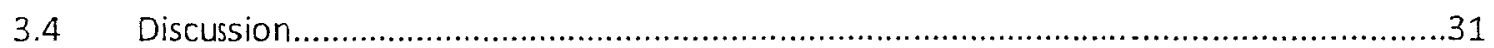

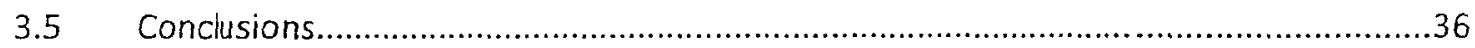

\section{Chapter 4:}

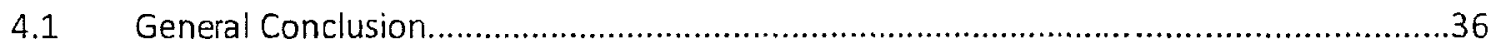

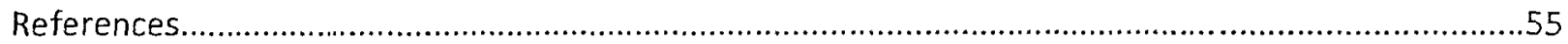




\section{LIST OF TABLES, FIGURES AND APPENDIXES}

\section{Chapter 2:}

Table 2.1. Properties of the native and crop species under consideration.

Table 2.2 Range of measured variables for each experimental trait

Table 2.3.1 Pairwise correlation between $I_{25}$ of glyphosate sensitive species and experimental trait parameters $(n=22)$

Table 2.3.2 Pairwise correlation between $I_{25}$ of glyphosate resistant species and experimental trait parameters $(n=12)$ 44

Table 2.4 Stepwise regression summary for select models of glyphosate resistance. .45

Figure 2.1 Non-metric multidimensional scaling (NMS) analysis showing the position of plant species along multiple axes according to their trait attributes.

\section{Chapter 3:}

Table 3.1 Summary of Arabidopsis lines and corresponding sensitivities to glyphosate .47

Tabie 3.2 Summary of Arabidopsis mutant phenotypes and responses to glyphosate. .49

Table 3.3 Percentage variation in leaf wax load and composition of six Landsberg erecta (Ler) eceriferum (cer) mutants. .50

Appendix 1.1 Leafcharacteristics of plant species used in this study...... .51

Appendix 1.2 Wax, trichome and stomata characteristics of plant species used in this study. .53 


\section{CHAPTER 1}

\section{GENERAL INTRODUCTION}

Of all forms of pesticides, the increased use of herbicides in the developed world has been the most startling, with global herbicide usage tripling since the mid-seventies (Boutin and Rogers, 2000). Agriculturally applied herbicides are now considered the most densely applied form of pesticide worldwide (Conacher and Conacher, 1986). Among all commercially available herbicides, glyphosate ( $\mathrm{N}$-(phosphonomethyl) glycine) is considered the most important due to its ability to kill most noxious weeds of concern, its affordability and ease of use (Brotherton et al., 2007). In Canada alone, as much as $80 \%$ of the volume of pesticides used is herbicides, and to date there has been roughly a three-fold increase in the total volume of herbicides used since the mid-70s. A 2008 survey of Ontario farm lands noted a 15\% increase in general agricultural pesticide usage since 2003, even though all surveys prior to the 2003 survey indicated a decrease in the pesticide usage in terms of kilogram/ ha applied due to the increased use of low-dose applied herbicides (McGee et al., 2010). Glyphosate usage was seen to increase by approximately $76 \%$, from $1,170,762 \mathrm{~kg}$ a.i. to $2,062,648 \mathrm{~kg}$ a.i., in this same time period (McGee et al., 2010).

Since the commercial introduction of herbicides, and the growing popularity of various agricultural intensification practices, their use has been implicated in many detrimental effects in ecosystems. One of the best examples of the direct effects of this increased herbicide usage can be seen in the effects on non-target habitats that are directly adjacent to cultivated fields

(White and Boutin, $200 \overline{7}^{-}$and references therein). These areas are at greater risk of herbicidal 
exposure, resulting from direct overspray or herbicidal drift, due to their proximity to farm lands (Boutin and Jobin, 1998). As more arable land is cultivated, this margin is steadily becoming an area of ecological significance.

The most prominent implications of herbicides in the ecosystem are their adverse and hard to predict effects on non-target plants. This includes the documented changes in plant biodiversity, based on the changes in plant development and growth seen at sub-lethal levels of herbicide contamination (Mahna and Heimecke, 1979). As a result, most major herbicides may also adversely impact local wildlife and aquatic populations by reducing food sources and changing the flora needed for survival and reproduction (Sullivan and Sullivan, 2003 and references therein).

Riemens, et al, (2008) examined the impact of sub-lethal herbicide levels on native plant species. Their approach incorporated questions on how applicable the greenhouse data results would be to field-grown plants. Results from this paper tentatively validate the view that herbicidal influences are detrimental to native plant species at the population level, thus making herbicides and their regulation an increasingly important area of ecological concern. Lastly, this study demonstrated that given sufficient experimental data it is possible to extrapolate between greenhouse experiments and field situations fairly accurately.

Phytotoxicity regulation guidelines (such as the Vegetative Vigor Test, USEPA, 1996) are the main tool used to estimate the ecological impact of chemicals such as herbicides. However, because the current pesticide phytotoxicity were first fashioned primarily to protect plants of 
economic interest (e.g. crops and ornamentals) from damage resulting from their exposure to pesticides, these tests are considered by many not comprehensive enough to fit this task.

Pesticide regulation is governed by two main agencies in North America (north of Mexico); the Canadian Pest Management Regulatory Agency (PMRA), and the Environmental Protection Agency (EPA) in the United States. Generally speaking, phytotoxicity guidelines in North America currently require dose-response testing data on ten different crop species prior to the registration of a new herbicide. These species include four monocotyledons from two families, and six dicotyledons from four families. The species tested must include corn [Zea mays], soybean [Glycine max] and a root crop, such as an onion [Allium cepa]. It is important to note the narrow taxonomic and life form range in this subset of species tests. Initially, the Organization for Economic Cooperation and Development (OECD - an assembly of 30 influential countries that regularly meet to discuss global issues adhered to similar guidelines except that only three species were required (OECD, 1984). They have recently updated their guideline to include a list of different wild plant species in an effort to make these tests more ecologically relevant (OECD, 2006).

The validity of using crop species as a model to estimate the impact of herbicides on all plant species, both crops and all non-target plants, is an ongoing debate in the scientific community. Noted limitations are the lack of variety in the test species. White and Boutin (2007) estimated the impact of herbicidal exposure to non-target plants by taxonomically pairing crops to a close wild/non-crop relative. They then obtained phytotoxicity data on these pairs based on the current regulatory guidelines. Their results showed that-while there was no 
significant difference in the sensitivity of crops and their related wild species, the range of herbicide sensitivity among cultivars of the same crop could be quite large. Since any crop may exist in a variety of different cultivars, some of which may be more or less sensitive to a given herbicide, the choice of a particular cultivar may intrinsically bias the results of a phytotoxicity test.

Most of the scientific community is in agreement that more work needs to be done to assess and determine the risks and ramifications of the increasing occurrence of toxic chemicals in the environment, and the ecosystem as a whole (Baird and Van den Brink, 2007). This is a particularly challenging endeavour as the ecosystems at risk are innately complex, consisting of diverse networks of plant species, each with unique habitat preferences that may influence the species sensitivity to a toxicant. Therefore, an understanding of these plant biological and ecological factors is essential to gain a viable measure of the harmful effects of herbicides on these organisms (Baird and Van den Brink, 2007).

Glyphosate, a contact herbicide, is absorbed into the plant primarily through the leaves. Since the initial patent by Monsanto Company in the early 1970s, glyphosate has grown to become the most commercially used agrochemical, with its global usage climbing (Baylis, 2000). One reason for its continued popularity is that despite its widespread usage, there is a relative lack of resistant weed biotypes, when compared to other herbicides. However, increased tolerance of weeds to this herbicide is an ongoing environmental concern, because this necessitates higher glyphosate concentrations to produce the same results (McGee et al., 2010). 


\section{CHAPTER 2:}

\section{INFLUENCE OF MIORPHOLOGICAL, PHYSIOLOGICAL AND}

ECOLOGICAL TRAITS ON THE RESPONSE OF PLANTS TO FOLIAR APPLIED HERBICIDES

\subsection{INTRODUCTION}

Herbicidal efficacy can be greatly influenced by multiple plant traits. These traits include growth habits, leaf morphology, life span, cuticular wax composition and leaf structure characteristics (for example the presence of trichomes, and stomata size and location) (Chachalis, et al., 2001a; Huangfu, et al., 2007; Wyrill and Burnside, 1976; Benzing and Burt, 1970). Herbicide absorption is generally aided by stomatal infiltration, while cuticular wax is often seen as an effective barrier to absorption (Chachalis, et al., 2001b). Species with high stomata density on their leaves may experience relatively higher levels of herbicide uptake, although the stomata are considered as a minimal route for foliar uptake (Huangfu et al., 2007). In addition, leaf surface structures such as trichomes may affect the ability of the herbicides to adhere to the surface of the leaf, thus further reducing the absorption and efficiency of foliar applied herbicides (Hess et al., 1974).

We hypothesize that plant species which differ in their traits (morphological, physiological and ecological) and habitat preference will experience predictable responses to herbicides, such that plants which have traits associated with higher herbicidal absorption will be more susceptible. The general objective is to further improve on species selection in phytotoxicity testing. Although several experiments have successfully been conducted analyzing 
single plant traits versus herbicidal efficacy, there is still a need to better understand the influence of an assemblage of traits on efficacy in order to improve species selection in phytotoxicity testing, given that thousands of plant species exist that need to be protected from herbicide drift/runoff, and given that a limited number of species can be used in phytotoxicity testing.

\subsection{MATERIAL AND METHODS}

All experiments on the native and crop species were conducted in the National Wildlife Research Centre of Environment Canada greenhouses located at Carleton University in Ottawa, Ontario, Canada between September 2008 and August 2010. Supplementary lights were added in fall through spring in order to maintain a consistent photoperiod of $16 \mathrm{~h}$ daylight. Temperatures varied from $16^{\circ} \mathrm{C}$ to $43^{\circ} \mathrm{C}$, and phytosynthetically active radiation (PAR) ranged from 285 (cloudy day) to $1951 \mu \mathrm{mol} \mathrm{m} \mathrm{m}^{-1} \mathrm{~s}^{-2}$ (sunny day).

\subsubsection{PLANT SPECIES SELECTION}

Plant species were chosen from readily available crop and non-crop species common to Canada. The majority of the species selected were native species common to North America. The species were further selected based on differences in their growth forms and overall morphology. Table 2.1 is a list of the native and crop species included in this project. 


\subsubsection{DETERMINATION OF IC 25}

The tank-mix herbicide formulation used in this study, consisted of Round-Up Original ${ }^{\circledR}$ (Monsanto Canada) containing $356 \mathrm{~g} / \mathrm{L}$ glyphosate [ $\mathrm{N}$-(phosphonomethyl) glycine] and the surfactant Agral, a wetting and spreading agent, (Agral $90^{\oplus}$, Norac Concepts, Ottawa, ON, Canada), which is a nonionic surfactant containing nonylphenoxy polyethyoxyethanol. Agral 90 was introduced, at $4 \mathrm{ml}$ per litre of solution, as a wetting and spreading agent.

Seeds used were obtained from commercial seed suppliers. Plants were grown from seed in trays and transplanted into $10 \mathrm{~cm}$-diameter by $9 \mathrm{~cm}$-high plastic pots containing a $3: 1$ Promix BX with Mycorise ${ }^{\circledR}$ Pro (Premier Horticulture) soil : sand mixture within 14 days of germination. One plant was transplanted per pot.

A one-time application of glyphosate was performed when plants (ranked according to size, at six replicates per dose) reached the three to five-leaf stage, as per current phytotoxic protocols (USEPA, 1996; OECD, 2006). Glyphosate was applied using a track spray booth (de Vries Manufacturing, Hollandale, MN, USA) equipped with a TeeJet $8002 \mathrm{E}$ flat-fan nozzle (Spraying Systems, Wheaton, IL, USA) delivering $6.75 \mathrm{ml} / \mathrm{m}^{2}$ at $206.84 \mathrm{kPa}$. Nine doses were used, ranging from $35 \mathrm{~g}-\mathrm{ai} / \mathrm{ha}$ to $286 \mathrm{~g}$-ai/ha in a geometric progression.

The plants were then left to grow for 21-28 days after which all the viable above-ground plant material was harvested and placed in a forced-air dryer for a minimum of $80 \mathrm{~h}$ at approximately $70^{\circ} \mathrm{C}$ for dry biomass determination. The $1 \mathrm{C}_{25}$ for each species was determined using the resulting biomass. 
The inhibition concentration $\left(I_{25}\right)$ is defined as the dosage that results in a $25 \%$ reduction in the endpoint considered compared with controls. The $I_{25}$ was estimated using nonlinear regression methods based on the relationships between herbicide dose and biomass (Environment Canada, 2005). Dose-response curves were individually fit using one of two models (logistic or gompertz). Alternatively, the linear interpolation method for sublethal toxicity (Norberg-King, 1993) was used to determine the $I_{25}$ in the event that no suitable model could be fitted, or the assumptions of normality and homogeneity of variance could not be met even when using transformed data.

\subsubsection{WAX ANALYSIS}

Wax analysis was performed on leaves of native plants at the growth stage deemed ready for phytotoxicity testing, based on current phytotoxicity testing protocol (USEPA, 1996; OECD, 2006). Plants were generally at the 3-5 leaf stage. It is important to note that while the growth stage of the plants may differ slightly between each species (although all were at the juvenile or pre-reproduction stage), all plants in a given species were in the same growth/life stage. All samples tested from each species were germinated, harvested and analyzed on the same day.

Epi and intracuticular waxes were extracted by immersing $>2 \mathrm{~cm}^{2}$ of plant leaves in 10 $\mathrm{ml}$ of chloroform for 30 seconds. Following this, a stream of nitrogen was used to gently evaporate the samples until they dried. An internal standard, 17:1 methylester, was then added to each sample to allow quantification of wax compounds. Next, the samples were dissolved in $50 \mathrm{ml}$ of $\mathrm{N}, \mathrm{O}$-bis (trimethylsilyl) trifluoroacetamıde (BSTFA) and derivatized at $80^{\circ} \mathrm{C}$ for $90 \mathrm{~min}$. 
The samples were then analyzed using gas-liquid chromatography and peaks assignment based on a comparison of their retention time and that of known references.

Wax load was determined by dividing the total wax load (obtained from an analysis of the resulting sample chromatograph) by the total area of the leaf sample analyzed (using Axiovision 4.7).

\subsubsection{PHYSIOLOGICAL PARAMETERS UNDER CONSIDERATION}

Traits under consideration for this experiment include leaf matrix and plant growth parameters. The following were methods used to determine the traits. Unless otherwise indicated, traits were determined on plants at the 3-5 leaf stage.

Plant growth parameters were used as a means of illustrating differences in interspecies

plant physiology. Variables under consideration include specific leaf areas (SLA), leaf area ratio (LAR), leaf weight fraction (LWF), unit leaf rate (ULR) and dry weights of different plant components. These variables were calculated using formulas published in Excel files by Hunt et al. (2002). Physiological parameters were calculated using the following formulae:

Specific Leaf Area $=($ average leaf area per plant $(\mathrm{cm})) /($ average leaf weight per plant $(\mathrm{g}))$

Leaf Area Ratio $=($ average leaf area per plant $(\mathrm{cm})) /($ average weight per plant $(\mathrm{g}))$

Leaf Weight Fraction $=($ average leaf weight per plant $(\mathrm{g})) /($ average total weight per plant $(\mathrm{g}))$ 
Unit leaf Rate $=\left(\operatorname{Ln} A_{2}-\operatorname{Ln} A_{1}\right) /\left(A_{2}-A_{1}\right) *\left(M_{2}-M_{1}\right)\left(t_{2}-t_{1}\right)$ where $A_{2}$ is the average leaf area at 4 weeks $M_{2}$ is the average total plant weight and $t_{2}$ is 28 days; $A_{1}, M_{1}$ and $t_{1}$ were taken as zero (Tholen et al., 2004).

Leaf measurements obtained included the average leaf area, average leaf length and average leaf width of all the leaves present on each plant. These variables were determined using Axiovision 4.7(Carl Zeiss) imaging software. The dry weights of the stems and leaves were obtained by cutting all mature leaves from the stem at the leaf-petiole junction, when plants were deemed ready for spray.

\subsubsection{RELATIVE GROWTH RATE}

Two forms of germination methods were used; the plants were either germinated in a tray or directly germinated in separate pots, and then thinned to one plant per pot. When trays were used, transplantation of the seedlings into separate pots was performed on the day when $\sim 30$ seedlings newly emerged. This day was taken as time zero. Trays were only used in two situations; the seeds either needed stratification or had very low germination rates.

In situations where plants were grown directly in pots approximately $10-15$ seeds were sown per pot in the greenhouse. Growth rates were started upon the germination of 25 seedlings (thinned to one per pot), and this was taken as the zero time point. Seedlings were then harvested at 7 day intervals for 4 weeks.

In both cases, RGR was determined as the slope of the graph of natural logarithm transformed plant dry weight and time. 


\subsubsection{STOMATA PARAMETERS}

Nail polish impressions of the epidermis were made at the point of maximum leaf width near the leaf mid rib. Replica impressions were taken from five different plants per species and made by applying a clear film of nail polish directly to the leaf surface. The film was allowed to dry for up to five hours in a well ventilated room, peeled off the leaf and then placed on a slide. The impression was kept immobile with the use of clear tape. Light microscopy was used to determine the stomata frequency and Axiovision 4.7 used to measure stomata parameters.

\subsubsection{TRICHOME DENSITY}

In order to account for not only the number of trichomes per unit area, but also the amount of leaf area covered by the trichomes, a qualitative unit referred to as the "\% leaf covered" was used. This percentage was then converted to a code, 0 to 4 , where 0 indicated that no trichomes were present on the present adaxial leaf surface and 4 was $>90 \%$ of the leaf covered by trichomes.

\subsubsection{STATISTICALANALYSIS}

All statistical analyses, with the exception of the non-metric multidimensional scaling (NMS) analysis were performed using JMP 9 (SAS Institute). The quantitative traits obtained in this experiment were transformed ( $\log$ and SQRT) and analyzed through stepwise regression to determine variables that provide the best model for herbicidal efficacy. Due to the limited number of variables measured, a select number of variables were used. These variables may be seen in the appropriate results sections. 
A non-metric multidimensional scaling (NMS) was performed to position plant species along multiple axes according to their trait attributes. This ordination technique is well suited for data that have no linear relationships. It is based on ranked distances between species space and environmental space (traits in this study). As recommended by McCune and Grace (2002), the pairwise plot distance matrix was built using the Sorensen (Bray-Curtis) dissimilarity measure. All data were log transformed except the trichome measures. SLA and LWF were not used in this analysis because of their high correlation with $L A R$, and $S W F$ and $L / S$, respectively. Only stomata measures for the adaxial side were incorporated in the analysis due to missing data for the abaxial side. Eupatorium maculatum was eliminated due to missing data. A preliminary run was conducted with six dimensions (axes) requested. The second run was conducted eliminating dimensions that did not contribute to reducing stress; therefore, three dimensions were used as recommended after the first run. A Pearson correlation analysis was conducted between species scores of axis 1 and the $I_{25}$ as well as the predictor variables in order to determine the most important variables explaining the species distribution along axis1.

\section{$2.3 \quad$ RESULTS}

Leaf traits of the thirty-three plant species studied are shown in Appendix 1.1 and 1.2. Since two varieties of Lactuca sativa were used, a total of 34 different plant types were tested in this study. One aspect the thirty-three species differed was their growth habit. The majority of the species had an erect growth habit, such as Helianthus annuus, while a few grew as rosettes (like Chrysanthemum leucanthemum) or had a grass-like form (Poaceae family). 
Trichome density was determined as the percentage of leaf area covered in an attempt to incorporate trichome morphology, density, and leaf distribution in the analysis. Trichome densities ranged from no trichomes (e.g. Lactuca sativa, Rumex crispus and seven other species) to $>90 \%$ coverage in Centaurea fontanum, Inula helenium and Centaurea cyanus (Appendix 1). The type of leaf trichomes also varied across the different species (data not shown). Trichome forms observed included glandular, slender uniseriate and stellate trichomes. Generally, the trichome density of the upper leaf surface was higher than that seen on the lower leaf surface.

With respect to stomata parameters, stomata frequency ranged from $2.00( \pm 0.6)$ to $48.17( \pm 3.21)$ stomata per field of view on the adaxial leaf layer in Campanula americana and Melilotus officinalis species respectively. Lolium perenne and Verbena hastata, had the lowest and highest abaxial stomata frequency, with no stomata on the Lolium perenne leaves and 106 $( \pm 16.5)$ stomata per field of view on the Verbena hastata bottom leaf layer. Stomata lengths ranged from $14.85( \pm 0.18) \mu \mathrm{m}$ in Melilotus officinalis to $49.94( \pm 1.35) \mu \mathrm{m}$ in Chrysanthemum leucanthemum on the adaxial leaf layer, and a maximum of 53.04 ( \pm 1.75 ) in Chrysanthemum leucanthemum on the abaxial side. Stomata frequency and length were not significantly correlated, although more stomata were generally seen on the abaxial leaf layer than on the abaxial (Appendix 1).

There were distinct variations in the physiological traits measured across the thirtythree species. Relative growth rates (RGR) ranged from $0.05 \mathrm{~g} \mathrm{~g}^{-1} \mathrm{~d}^{-1}\left(R^{2}=0.8482\right)$ (Phalaris 
arundinacea) to $0.289 \mathrm{~g} \mathrm{~g}^{-1} \mathrm{~d}^{1}\left(\mathrm{R}^{2}=0.9516\right)$ (Capsella bursa-pastoris). In general, members of the Poaceae family grew at a slower rate than broadleaved species (Appendix 1.1).

A large range in total upper leaf surface area at the time of spray was noted in the tested species. The average total leaf surface area was dependent on the number of leaves on the plants at the time of spray, thus making the plant stage at the time of spray an important variable. The leaf areas ranged from $3.03( \pm 0.38) \mathrm{cm}^{2}$ (Bouteloua gracilis) to $62( \pm 7.36) \mathrm{cm}^{2}$ (Lycopus americanus). Comparatively, members of the Poaceae family had less surface area than broadleaved species at the time of spray. In general, there was a large variation in the plant physiological growth parameter ratios (Table 2.2). Specific leaf area (SLA; leaf area/leaf dry mass), an indication of the plant resource allocation strategy, ranged from 52 to 1450 $\mathrm{g} / \mathrm{cm}^{2}$. Unit leaf rate (ULR; increase of plant biomass per unit leaf area per day) ranged from 10.42 to $315.82 \mathrm{~g} / \mathrm{cm}^{2} /$ day while the Leaf area ratio (LAR; plant area per biomass) ranged from $34.96-1105.35 \mathrm{~cm}^{2} / \mathrm{g}$. The leaf weight fraction (LWF) ranged from 0.60 to 0.90, while the stem weight fraction (SWF) ranged from 0.07 to 0.39 .

Pairwise correlations, using untransformed data (results not shown), revealed significant relationships between selected variables. Some of the best positive correlations were noted between SLA and LAR $(r=0.971, P<.0001), L W F$ and SWF $(r=-1.0, p<0.0001)$, and LWF and leaf stem dry weight ratio $(\mathrm{L} / \mathrm{S})(\mathrm{r}=0.918 ., \mathrm{p}<0.0001)$. These correlations were taken into consideration when performing further analysis. Other significant correlations noted included ULR with the different dry weights measured as well as the different dry weights measured. 
Herbicidal efficacy was measured as the twenty-five percent inhibitory concentration $\left(I C_{25}\right)$. The $I C_{25}$ is the concentration of the herbicide required to cause a $25 \%$ reduction in the aboveground plant dry weight. From this value, the resistance ratio was calculated, which is the ratio of the species' $I_{25}$ and the minimum $\mathbb{K}_{25}$. Based on the current data, a resistance ratio of 5.0 was taken as the cut off for herbicidal susceptibility and species with a ratio above 5.0 (or an $I_{25}$ above $235 \mathrm{~g}$-ai/ha) were deemed to be fairly resistant to glyphosate. This cut off was chosen based on a maximum tested dosage of $286 \mathrm{~g}$-ai/ha. Of the thirty-three species, 12 and 22 were above and below the 5.0 resistance ratio mark, respectively.

Pairwise correlation analysis was performed using the $\mathrm{IC}_{25}$ and the measured plant parameters, separately for species with a resistance ratio above and below 5.0. Among the 18 quantitative parameters, only relative growth rate ( $R G R$, positive correlation) and the leaf area ratio (LAR, negative correlation) were significant at the 0.05 level, but multiple trends were noticed (Table 2.3.1). Apart from RGR, near significant positive correlations were noted between leaf weight fraction, unit leaf ratio, and biomass of the different parts and glyphosate sensitivity. Negative trends were noted between leaf area ratio, wax load, trichome density (adaxial), specific leaf area, and herbicidal sensitivity but none were significant. Alternatively, pairwise correlation results of the species deemed resistant to glyphosate ( $n=12$; Table 2.3.2) shows that traits related to leaf and stem weight have significant relationships to efficacy.

The influence of life history traits such as plant family, life span and growth habit on efficacy where also examined. Plant families of the thirty-three species used for this project included the Asteraceae family $(n=10)$, Poaceae family $(n=6)$, Polygonaceae family $(n=3)$, 
Brassicaceae family $(n=2)$, Fabaceae family $(n=2)$, Solanaceae family $(n=2)$, Lamiaceae family $(n=2)$ and a single member of the Campanulaceae, Caryophyllaceae, Papaveraceae, Phytolaccaceae, Scrophulariaceae and Verbenaceae families respectively.

Two varieties of Lactuca sativa were used in the determination of traits. The variety Tom Thumb is one of the "capitata variety" and is also called cabbage lettuce due to its leaves arranged in a dense rosette. The variety oak leaf is one of the "crispa variety" distinguished by a loose rosette of leaves that are curled and oak-leaved in shape. The correlation among all traits between the two varieties was very high $(r=0.99)$ and their $I_{25}$ s were fairly close, at 112 and $170 \mathrm{~g}$ ai / ha. They differ mostly in their leaf/stem dry weight ratio and wax content (Appendix 1). Likewise, trait values for the two related species, Helianthus annuus and Helianthus strumosus were highly correlated $(r=0.96)$ and their $I_{25} s$ were very similar at 52 and $60 \mathrm{~g}$ ai / ha. They differ in their wax content and stomata frequency.

Although the average $\mathrm{IC}_{25}$ values of each life span set was fairly large, a general trend of decreasing herbicidal efficacy with increasing length of life span was noted. The average $I_{25}$ of annuals $(n=9)$ and perennials $(n=24)$ was $186( \pm 41)$ and $284( \pm 59)$ g ai/ha respectively, making annuals sensitive and perennials resistant to glyphosate (according to maximum glyphosate concentration used). Also observed was that the average leaf surface areas were highest for annuals than perennials. This decreasing trend was also observed in SLA, and approximated (i.e. less significant relationships) in LAR and LWF. These trends seem to indicate that the difference in leaf biomass allocation may play a role in herbicidal efficacy among plants with different life spans. 
Leaf cuticular wax loads ranged from $0.24 \mu \mathrm{g} / \mathrm{cm}^{2}$ (Lactuca sativa var. Tom Thumb) to $30.4 \mathrm{\mu g} / \mathrm{cm}^{2}$ (Inula helenium). Although the correlation between wax load and herbicidal sensitivity was weak, it was noted that most species with high $\mathrm{IC}_{25}$ values, and thus fairly resistant to glyphosate, had low wax loads (i.e. less than $2.0 \mu \mathrm{g} / \mathrm{cm}^{2}$ ). For example, out of the twelve species deemed resistant to glyphosate eight had wax loads less than $2.0 \mu \mathrm{g} / \mathrm{cm}^{2}$.

Multiple predictor models of glyphosate effects (using the $\mathrm{IC}_{25}$ as the response variable) were determined using forward selection stepwise regression, with the standard p-value threshold as the selection criteria. The model determined using nine of the quantitative predictor variables of the thirty-three species was overall a poor fit, while a slightly better model of herbicidal susceptibility was noted when only species deemed sensitive to glyphosate $(n=22$, were used (Table 2.4). Eupatorium maculatum was eliminated from this analysis because several traits could not be measured and were therefore missing (Appendix 1.2).

Results of the NMS analysis show that axis 1 explained $51.5 \%$ of the variance while axes 2 and 3 explained $12.3 \%$ and $17.8 \%$ of the variance, respectively. The positioning of plant species in a multidimensional plan is shown in Figure 1. Grasses (in italics) are situated on the left side of the graph while Asteraceae (in bold) and the 12 least sensitive species (square label) tended to be situated on the right handside. Variables explaining the positioning of the species along axis 1 were leaf dry weight, leaf stem dry weight ratio $(L / S)$ and total dry weight on the positive side while variables negatively correlated with axis I are leaf length width ratio (L/W) and stem weight fraction (SWF). Vicia cracca (vicia) with its narrow leaves was positioned on the negative side together with grasses. Prunella vulgaris (prun) with its high leaf dry weight 
(Appendix 1) was positioned on the right hand side. The $I_{25}$ was weakly correlated with axis 1 $(r=0.32, p=0.073)$

\subsection{DISCUSSION}

Glyphosate is a systemic, non-selective foliar applied contact herbicide effective for the control of a wide range of species. There are two recognized pathways for foliar herbicidal uptake, stomata infiltration and cuticle penetration. Once absorbed into the plants, approximately $70 \%$ of foliar absorbed glyphosate can be translocated either up the plant to the shoot apices or down the plant into the roots (Shaner et al., 2006). Once inside the plant, glyphosate functions by inhibiting the enzyme 5-enolpyruvyshikimate 3-phosphate synthase (EPSPS). EPSPS is an essential component of the shikimate biosynthetic pathway. This pathway is necessary for the production of auxin, selected aromatic amino acids, phytoalexins, lignin, folic acid, plastoquinones and many other secondary products. Shaner et al. (2006) surmised that about $30 \%$ of carbon fixed through photosynthetic reactions is used up through this pathway. The inhibition of EPSPS deregulates this pathway causing the accumulation of shikimate and shikimate-3-phosphate. Symptoms of glyphosate toxicity include chlorois, necrosis, stunted plant growth and death.

Research has shown that the efficacy of foliar applied herbicides may be strongly correlated to the amount that is absorbed, and that the amount absorbed usually varies with morphological and anatomical leaf traits (Hoss et al., 2003; Chachalis et al., 2001b). Since glyphosate efficacy is directly related to the amount that penetrates the plant cuticle (Belles et al., 2006), differences in epidermal traits that may hinder uptake (such as trichome and stomata 
density) were used to elucidate the complex relationship between plant traits and herbicide sensitivity.

A review of the scientific literature showed that the relationship between plant traits (physiological, morphological and ecological) and herbicide efficacy is a complex one that may possibly involve multiple mechanisms (Chachalis et al., 2001a; Huangfu et al., 2007). Although multiple traits have been suggested as key in explaining species sensitivity, small sample sizes, limited species data and a lack of cohesion in experimental conditions IImits the application of results to other non-native species.

Thirty-three unique plant species, commonly found in Canada, were used to examine the relationship between herbicides and plant ecological, physiological and leaf epidermal traits. The principal aim of this project was to see if differences in the above noted traits may be used to explain the differences in plant responses to glyphosate.

The relationship between herbicidal efficacy and trichome density is complex due to the variety of leaf epidermal trichomes available. Trichomes increase herbicide resistance when they hinder the wetting and spreading of herbicide droplets (Hull et al., 1982), create air pockets that inhibit contact between the chemical and the leaf surface (Hess et al., 1974) and/or cause droplets to shatter or bounce away from the leaf surface. Conversely, they may decrease plant resistance to herbicides by providing an entry site for foliar-applied herbicides (Benzing and Burt, 1970).

As Appendix 1.2 shows, there exists a vast range of differences in the trichome density of the experimental species. Hypothetically, since trichomes would hinder herbicides from 
coming into contact with the leaf surface, and thus obstruct herbicides from penetrating the cuticle and being taken up by the plant, it was expected that increased trichome density would result in increased resistance to glyphosate. However, the negative correlation between these variables $\left(R^{2}=-0.3150, P=0.16\right)$ was neither strong nor significant.

A trend noted was that the majority of resistant species had trichome coverage on more than $75 \%$ of their leaf surface (Appendix 1). For example, Inula helenium $\left(1 C_{25}=761 \mathrm{~g} \mathrm{ai} / \mathrm{ha}\right.$ ), Cerastium fontanum (391 g ai/ ha), Centaurea cyanus (234.56 g ai/ ha), Rudbeckia hirta (1043 g ai/ ha) and Verbena hastate ( $450 \mathrm{~g} \mathrm{ai/} \mathrm{ha)} \mathrm{have} \mathrm{the} \mathrm{highest} \mathrm{percentage} \mathrm{of} \mathrm{leaf} \mathrm{area} \mathrm{covered} \mathrm{by}$ trichomes and also have correspondently high $I_{25}$ values. In contrast, the two Helianthus species exhibited high trichome coverage although their $I_{25}$ was very low.

Cuticular wax deposition may affect the efficiency of herbicide uptake in a variety of manners. Since leaf waxes have been known to hinder the absorption of herbicides through the leaves, it is expected that the quantity and composition of the cuticle wax may be relevant in phytotoxicity testing. Changes in cuticle and wax deposition may affect the interception, retention, penetration and / or translocation of glyphosate to its site of action. The interaction of glyphosate, the surfactant and wax composition may also be of importance. As mentioned above, eight of the most resistant species (with resistance ratios above 5.0 ) had very low wax content. Conversely, the four species (including one of the Lactuca variety) with high wax content were both very sensitive and very resistant to glyphosate. The two varieties of Lactuca and the closely related species of Helianthus both differed in their wax content but showed little differences in their $I C_{25}$, further highlighting the low importance of wax content int 
explaining sensitivity to glyphosate. However, it is important to note that although the wax load was taken into consideration, due to the high level of complexity involved using multiple plant species, wax composition was not determined. Multiple studies have indicated that the wax composition may be a significant indication of herbicidal efficacy (Wilkinson, 1980; Wilkinson and Mayeux, 1987; Chachalis et al., 2001a; Chachalis et al., 2001b; Mayeux and Jordan, 1980) and this trait should be considered for future studies.

Since glyphosate is a foliar applied herbicide, the available leaf surface area was a variable of particular interest. Due to the importance of the leaf for this form of herbicide, multiple leaf parameters were considered. It is important to note that although leaf area depends on both the number of leaves on the plants and their size, all plant traits were measured at the 3-5 leaf stage (according to current phytotoxicity testing protocol), thus standardizing the experimental conditions. Looking at the thirty-three species, no significant relationship was observed between available leaf surface area and glyphosate sensitivity. However, an interspecies comparison between the Poaceae family $(n=6)$ and the Asteraceae family $(n=10)$ revealed that, on average, members of the Asteraceae family had more than twice the total average leaf surface area $\left(9.38 \mathrm{~cm}^{2}\right.$ versus $\left.21.50 \mathrm{~cm}^{2}\right)$ and members of the Poaceae family were over three times more sensitive to glyphosate than members of the Asteraceae family. It may be that in further studies on the importance of plant traits for explaining herbicide sensitivity, leaf area rather than leaf number should be standardized.

Stomata parameters, such as their size and density, may be considered an important trait for the estimation of herbicide sensitivity, since stomata penetration is a pathway for 
herbicide uptake. Furthermore, both stepwise regression models show sto mata parameters are an important trait for the prediction of species specific efficacy (Table 2.4). However, research has shown that as little as $10 \%$ or less of foliar herbicide is taken up by this pathway (Wang and Liu, 2007). The lack of importance of this mode of entry seems to be reflected in our findings since no correlation was noted between either stomata density (on both the adaxial and abaxial layer) or stomata length and glyphosate sensitivity.

The relationship between plant physiological traits and herbicidal sensitivity was also examined in detail. One of the strictest requirements for phytotoxicity testing is the life stage of the plant. Typically plants are required to be in the 3-5 leaf stage. It has been noted that as plants mature, their response to foliar applied herbicides change (Chachalis et al., 2001; Gonzalez-Torralva et al., 2010). The increased sensitivity of plants in this early developmental stage is commonly attributed to the lack of establishment of morphological traits (such as trichome density and thicker wax layers on leaf surfaces) that may hinder the retention, and later absorption, of a foliar herbicide. The experimental plant life stage also alters physiological traits such as relative growth rate (RGR) and growth parameters like SLA, ULR, LAR and the leaf and stem weight fractions, mainly due to the size of the plant organs at this time.

The $\log 10$ transformation of the relative growth rate versus the efficacy of sensitive species ( $n=22)$, exhibited one of the most significant relationships to herbicidal efficacy of all the measured traits. This suggests that increased plant growth rate, and thus enhanced metabolic processes (Muzik, 1976), may inhibit the efficacy of foliar-applied herbicides. RGR -was not significantly correlated with any other trait measured. 
Generally speaking, interspecies SLA and LAR were found to be highly correlated (Poorter and Remkes, 1990). Specific leaf area is an indication of the plant resource allocation strategy and an index of leaf thickness. Low SLA values show efficient conservation of nutrients, while high SLA values indicate rapid biomass production (Poorter and de Jong, 1999). The results showed a fairly negative trend between SLA and herbicidal efficacy. It is also relevant to note that SLA and LAR generally declines with leaf age, thus suggesting that standardizing plant age in phytotoxicity testing may need to be considered. Of all the plant physiological traits, the strongest relationship observed was the negative trend between herbicidal efficacy and LAR, using the most sensitive species.

Plant qualitative ecological traits examined in this project were the family of the plants, their growth habit and their life span. Some trends were noted. In particular, interfamily variations were noted, although small sample sizes hinder their definitive itemization. The following trend was noted, using families with more than one member, based on decreasing average resistance to glyphosate:

Polygonaceae > Asteraceae $>$ Fabaceae $>$ Lamiaceae> Poaceae> Solanaceae > Brassicaceae

i.e Polygonaceae was the most resistant family to glyphosate and Brassicaceae the most sensitive.

This study revealed that measured traits taken separately were not very good at predicting glyphosate sensitivity in terms of the $I_{25}$ measured on the different species. Further analyses taking into account traits as a group revealed some patterns, albeit not well-defined. The forward stepwise regression as well as the NMS analysis indicated that, as expected, 
herbicidal susceptibility is complex and relies on multiple traits. There is a clear separation between the species of the Poaceae family and other species, mostly explained by leaf shape. Relative growth rate seemed to be an important variable to consider for the Poaceae and the 21 sensitive species, although an unexpected positive relationship was observed.

\subsection{CONCLUSION}

The correlations between the $\mathrm{IC}_{25}$ values (of glyphosate sensitive plants) and plant traits provided important information regarding the importance of traits to herbicidal efficacy. The RGR and LAR traits were the best predictors of herbicidal efficacy for sensitive species. On the other hand, stomata, trichomes and wax load did not appear be relevant indicators of sensitivity to foliar-applied herbicides. This project attempts to clarify the relationship between herbicidal efficacy and plant traits, and shows that glyphosate efficacy in certain plant families (Poaceae and Asteraceae) can be predicated by a given subset of traits. 
CHAPTER 3:

INFLUENCE OF MORPHOLOGICAL PHENOTYPIC TRAITS ON THE EFFICACY OF ARABIDOPSIS MUTANTS TO FOLIAR APPLIED HERBICIDES

\section{$3.1 \quad$ INTRODUCTION}

Arabidopsis thaliana, a member of the mustard (Brassicaceae) family, is a small flowering plant found in multiple areas of the world (Alonso-Blanco and Koornneef, 2000). To date, more than 750 natural accessions (distinct varieties) of this species have been collected from around the world (Alonso-Blanco and Koornneef, 2000). Arabidopsis thaliana is also an important model organism (Meinke et al., 1998). In addition to natural differences between accessions, the use of this plant in genetic research has resulted in a large number of readily available mutants with documented altered leaf traits.

This project aimed to use Arabidopsis mutants, which each differ in one primary foliar trait, to observe the extent by which changes in leaf traits affect herbicide sensitivity. Analyzing mutants of Arabidopsis will be instrumental in understanding the effects of altered leaf traits on phytotoxicity testing. Although Arabidopsis ecotypes have previously been used to examine glyphosate-resistance mechanisms (Brotherton et al,. 2007), this is to our knowledge the first time that Arabidopsis leaf mutants have been used to examine the effect of leaf traits on glyphosate sensitivity. 
Applications of these findings may help elucidate the relationship between herbicidal sensitivity and leaf traits. It may also prove useful to both weed management strategies and the creation of more ecologically relevant phytotoxicity testing guidelines.

\subsection{MATERIAL AND METHODS}

Experiments with Arabidopsis plants were conducted in growth chambers at the National Wildlife Research Centre of Environment Canada. The photon flux from cool white fluorescent and incandescent lamps during the $16 \mathrm{~h} / 8 \mathrm{~h}$ photoperiod was $120-150 \mu \mathrm{mol} / \mathrm{m}^{2} \mathrm{sec}$ with a $16 \mathrm{~h} / 8 \mathrm{~h}$ photoperiod. Plants were watered daily to keep the soil moist. Temperature was set at $22^{\circ} \mathrm{C}$ during daylight and at $15^{\circ} \mathrm{C}$ during darkness. The herbicide used consisted of RoundUp Original ${ }^{\oplus}$ (Monsanto Canada) containing $356 \mathrm{~g} / \mathrm{L}$ glyphosate [ $\mathrm{N}$-(phosphonomethyl) glycine] and the surfactant Agral (Agral 90®; Norac Concepts, Ottawa, ON, Canada), which is a nonionic surfactant containing nonylphenoxy polyethyoxyethanol. Agral 90 was introduced, as per the recommended label rate, as a wetting and spreading agent.

Arabidopsis seeds were obtained from two sources: Arabidopsis Biological Resource Center (The Ohio State University, 1060 Carmack Road,Columbus, OH 43210 USA) and Dr. Owen Rowland (Department of Biology and Institute of Biochemistry, Carleton University). Table 3.1 illustrates the different Arabidopsis mutants used in this experiment. 
Seeds were germinated by cold stratifying them at $4^{\circ} \mathrm{C}$ for three days. Seedlings were transplanted into $10 \mathrm{~cm}$-diameter by $9 \mathrm{~cm}$-high plastic pots containing a $3: 1$ non-mycorrhizae soil: sand mixture within 14 days of germination at one plant per pot.

A one-time application of glyphosate was performed when plants reached the end of the vegetative stage, as indicated by the presence of a bolt. Six replicates were used per dose. Glyphosate was applied using a track spray booth (de Vries Manufacturing, Hollandale, MN, USA) equipped with a Teejet 8002 E flat-fan nozzle (Spraying Systems, Wheaton, IL, USA) delivering $6.75 \mathrm{ml} / \mathrm{m}^{2}$ at $206.84 \mathrm{kPa}$. Nine doses were used, ranging from $35 \mathrm{~g}$ ai/ha to $285.58 \mathrm{~g}$ ai/ha in a geometric progression. The plants were then left to grow for 21 days, after which all the viable above-ground plant material was harvested and placed in a forced-air oven for a minimum of $80 \mathrm{~h}$ at approximately $70^{\circ} \mathrm{C}$ for dry biomass determination.

\subsubsection{Statistical analysis}

The inhibition concentration $\left(\mathrm{IC}_{25}-\mathrm{g}\right.$-ai/ha) for each Arabidopsis line, defined as the dosage that results in a $25 \%$ reduction in biomass compared with controls, was determined using the resulting plant biomass. The $I_{25}$ was estimated using nonlinear regression methods based on the relationships between herbicide dose and biomass (Environment Canada, 2005). The non-regression models used included Gompertz and the Logistic sigmoid curve models. Alternatively, the linear interpolation method (ICPIN) for sublethal toxicity (Norberg-King, 1993) was used to determine the $I C_{25}$ in the event that no suitable model could be fitted, or the assumptions of normality and homogeneity of variance could not be met even on transformed data. 


\subsection{RESULTS}

Arabidopsis mutants were sprayed at the end of their vegetative stage to best estimate the plant size required for phytotoxicity testing. Two background wild-type varieties, Columbia (Col-0) and Landsberg erecta (Ler), were used. Plants from the Ler-WT background had smaller and rounder leaves, and on average significantly smaller total leaf surface areas than Col-WT. Furthermore, the adaxial surface of Ler -WT had a visibly lower trichome density than Col-WT, giving it a smoother more glossy appearance. These properties made the background of the mutant an important variable.

Based on their major phenotypic differences from the respective wild-type ecotypes, the mutants were placed into three categories. These categories are: 1) those that differ in leaf morphology, 2) those that differ in their stomata or trichome density, and 3) those that differ in their cuticular wax load and/or composition. All the wax cuticle mutants were in the Ler-WT background, while both backgrounds were used in the other two categories. Table 3.2 shows the differences between these mutants and their corresponding wild-type ecotypes (WT). Data on the three major Arabidopsis mutant traits used, in general, were available in the open literature.

The eceriferum (cer) mutations are a group of induced epicuticular wax mutants commonly used to isolate genes involved in epicuticular wax biosynthesis (Jenks et al., 1995). The following are some of the major documented differences in leaf cuticular wax between the cer mutants and their corresponding WT ecotype (Jenks et al., 1995). Cer1 has less alkanes than

WT. Cer3 differs from its WT in free fatty acids (55\% less), aldehydes ( $17 \%$ less), and alkanes ( 
$30 \%$ less). Cer 8 has elevated C30 free fatty acids, while the total amount of the other cuticular wax components is generally less than the WT. The major differences between cer16 and WT are less alkanes, and more primary alcohols. Cer4 mutants are almost completely devoid of primary alcohols and wax esters, although other components are increased such that the total leaf wax load is about the same as wild-type. The most sensitive mutant was cer 1 (17 $\mathrm{g}$ ai/ha), while cer16 (85 g-ai/ha) was the most resistant to glyphosate (Table 3.3).

Arabidopsis trichomes on the WT leaf surface are single epidermal cells seen on most parts of the plant. The trichomes appear to the naked eye as a single stalk that branches out to three points. The trichome mutants considered here differ from WT in either trichome morphology and/or distribution on the leaf surface. Comparing the trichome-less mutants g/11, g/3-1 and their corresponding wild-type ecotype (Ler), it was observed that a reduction in trichome density correlated with a $\sim 40 \%$ decrease in sensitivity to glyphosate (Table 3.2 ). In contrast, increasing trichome density, seen in bsh, correlated with a $\sim 90 \%$ increase in sensitivity to glyphosate. With regards to stomata density, an increase in this trait increased sensitivity to glyphosate (Table 3.2). The most sensitive mutants tested in this study were $t m m 1$ and sdd1, both of which have increased stomata densities. Lastly, by comparing the leaf developmental mutants bop1 bop2 and as-1 with their respective wild-type ecotype (Col-0), decreasing the available leaf area from $11.37 \mathrm{~cm}^{2}$ to $10.47 . \mathrm{cm}^{2}$ and changing the leaf morphology correlated with a decrease in sensitivity to glyphosate.

The following trends, although not statistically significant, were noted when comparing the pairwise correlations of the percentage of each given wax-component variables and 
herbicidal efficacy (Table 3.2). The percentage of ester components was best correlated to glyphosate $I C_{25}$ values $\left(R^{2}=0.8085\right)$, followed by the aldehyde components $\left.R^{2}=0.5044\right)$. Ketone $\left(R^{2}=0.2501\right)$ and alcohol $\left(R^{2}=0.2145\right)$ components were fairly well correlated with herbicidal sensitivity as well. No trend, negative or positive, was observed between leaf wax load (wax load per leaf area) and herbicidal efficacy. For instance cer 16 , with a wax load of $64.5 \mu \mathrm{g} / \mathrm{dm}$, would be hypothesized to be more sensitive than Ler WT $(97.2 \mu \mathrm{g} / \mathrm{dm})$, but the results show the opposite trend, with Ler WT being almost twice as sensitive as cer16.

Although the blade-on-petiole mutant (bop1 bop2) had only slightly less total average leaf surface area than the corresponding Col-WT ecotype $\left(10.47 \mathrm{~cm}^{2}\right.$ versus $\left.11.37 \mathrm{~cm}^{2}\right)$, its $I C_{25}$ of $35 \mathrm{~g}$-ai/ha was higher than the $I_{25} 23 \mathrm{~g}$-ai/ha of Col-WT (Table 3.2). The mutants most sensitive to glyphosate were too many mouths (tmm1), stomatal density distribution (sdd1) and bushy (bsh). The most resistant mutants were bop 1 bop 2 and glabrous 1 and 3 .

\subsection{DISCUSSION}

Many examples of research on herbicidal efficacy and plant traits are readily available in the general scientific literature (Wilkinson, 1980; Pratley, et al., 1999; Poorter et al., 1999; Riethmuller-Haage et al., 2007; Riemens et al., 2008; Huangfu et al., 2007 Chachalis et al., 2001a). Although it is generally accepted that traits which hinder the ability of a foliar applied (and absorbed) herbicides, such as glyphosate, to reach the leaf surface would reduce herbicidal efficacy, there is still debate over the relevance of these plant traits and/or the extent of their importance (Pratley et al., 1999; Reithmuller-Haage et al., 2007). 
Glyphosate (N-[phosphonomethyl] glycine) is a systemic, non-selective herbicide effective for the control of a wide range of species. As an anionic contact herbicide, its efficacy relies on the extent by which it is absorbed by the leaf epidermis and subsequently translocated to its site of action (Belles et al., 2006). Furthermore, since the majority of glyphosate enters the plant either by penetrating the cuticle or the stomata, changes in epidermal traits that influence the amount of available cuticle (such as leaf surface area, stomata density and trichome density) are expected to have an effect on glyphosate efficacy. Of the two uptake pathways, stomata infiltration is considered to be the minor uptake pathway (Wang and Lui, 2007), although no detailed comparative study of uptake mechanisms has been conducted.

The relationship between plant morphological traits and herbicidal efficacy is complex and may involve many competing mechanisms. Past studies have been unable to conclusively determine the importance of each trait, even when using similar plant species, since these plants often differ in more than one trait making such an analysis unrealistic. The present study sought to assess the importance of individual leaf morphological traits on herbicidal efficacy by examining differences in glyphosate resistance between mutants within a species. The model plant Arabidopsis thaliana was chosen as a large number of well-characterized mutants affecting leaf morphology are readily availabie.

The cuticle is a layer composed mostly of lipids covering the outer aerial surfaces of land plants. This layer consists of an esterified polymer of long-chain (C16 and C18) fatty acids (cutin) as well as non-polymerized very-long-chain (C20-C34) intracuticular and epicuticular waxes (Kolattukudy, 1980). Its general functions include the prevention of uncontrolled water loss 
and deterring of microbial pathogens and pests, but its ability to influence the herbicidal efficacy is the focus of the present study. Since glyphosate efficacy is directly related to its ability to penetrate the leaf surface, the ability of this waxy layer to influence both foliar retention and uptake makes it a trait of particular interest.

Although changes in cuticle characteristics have been proposed to influence herbicide resistance (Baker, 1980; Hess and Falk, 1990), there is still ambiguity over the role of wax components in herbicidal efficacy (Chachalis et al., 2001b). When examining the effect of cuticular wax on the penetration of foliar applied herbicides, there are two parameters of interest: wax load per leaf area (and/or cuticle thickness - not measured in this study) and the leaf wax composition. Both of these traits were examined. Increased cuticle thickness has been proposed to result in less glyphosate absorption, while decreased cuticle thickness can increase glyphosate penetration and uptake (Santier and Chamel, 1992). It is important to note that these findings are usually observed in isolated cases and no conclusive relationship exists between either cuticle thickness or wax content and herbicidal penetration (Santier and Chamel, 1992).

The wax layer, by definition, is composed almost entirely of hydrophobic molecules and variations in its components have been noted in different species (Baker, 1980). The leaf cuticle may contain varying amounts of hydrocarbon chains, such as free fatty acids, fatty alcohols, wax esters, fatty aldehydes, fatty ketones and triterpenes (Baker, 1980). Of the above mentioned components, alcohols and acids have a polar moiety (Baker, 1980) and this 
reduction in hydrophobicity may play a role in the absorption of the ionic glyphosate herbicide (Santier and Chamel, 1992; Chachalis et al., 2001b).

In Arabidopsis thaliana, wild-type leaf epicuticular wax forms as a smooth continuous layer over the epidermal surface, and is about to 10 -fold less than the stem epicuticular wax layer that has a crystalline form (Jenks et al., 1995). Since the leaves are the primary uptake site for foliar herbicides, only changes in the leaf wax will be discussed. Cer mutants are available in different Arabidopsis ecotype backgrounds (Col-0, Ler, WS, and C24). In order to simplify the interpretation of the results, only cer mutants affecting leaf wax from the Landsberg erecta (Ler) background were compared. The range in percentage of each wax component is shown in Table 3.3. Overall, all wax mutant wax phenotypes, except cer16 were more sensitive than the Ler WT, suggesting that when estimating herbicidal efficacy, wax composition may play a more important role than wax load.

Two mutants were used to observe the effect of changes in leaf phenotypes on glyphosate sensitivity. These are asymmetric leaves (as1) and blade-on-petiole (bop1 bop2) (Xu et al., 2008; Hepworth et al., 2005). BLADE-ON-PETIOLE1 and 2 (BOP1 BOP2) encode functionally redundant transcriptional co-regulators that are expressed primarily in the lateral boundaries of organs. bop1 bop 2 mutant is characterized by leafy petioles and elongated leaves (Hepworth et al., 2005), while the as1 leaves are smaller and more curved. Both these phenotypes were less sensitive than their Col-WT.

Asymmetric leaves 1 (as1) is an Arabidopsis leaf mutant that can be identified by their curled, triangular-shaped leaves (Xu et al., 2008). This mutation not only results in a lower total 
leaf surface area, but due to the curved nature of the leaves, even less surface area is available for spray deposition during glyphosate testing. as 1 had more than a three-fold less average total leaf surface area than the Col-WT and was also three times less sensitive to glyphosate (Table 3.2)

Leaf trichomes are an especially interesting trait, since they may either decrease or increase herbicidal efficacy. Trichomes increase herbicide resistance when they hinder the wetting and spreading of droplets (Hull et al., 1982), create air pockets that inhibit contact between the chemical and the leaf surface (Hess et al., 1974), and/or cause droplets to shatter or bounce away from the leaf surface. Conversely, they may decrease plant resistance to herbicides by providing an entry site for foliar-applied herbicides (Benzing and Burt, 1970).

A comparison of bushy (bsh), a mutant with increased trichome density (Table 3.2), and its corresponding wild-type ecotype (Col-WT) revealed that increasing trichome density resulted in a 10-fold increase in sensitivity to glyphosate. Two forms of the $g /$ phenotype were examined. g/1-1 lacks trichomes on the leaves and stem, and g/3-1 has a reduced number of trichomes. Although g/1-1 has almost twice the surface area of g/3-1 (data not shown), its $I C_{25}$ was affected to the same extent by the reduction in trichome density.

Although the general consensus seems to be that uptake of glyphosate via stomata infiltration is minor compared to that through the cuticle (Wang and Lui, 2007), and stomatal uptake is dependent on a host of different factors (including the surface tension of the solution and environmental conditions), it is understood that the amount of uptake through stomata varies greatly between plant species (Wang and Lui, 2007). The effect of increased stomata 
density on herbicidal sensitivity was examined using two mutants, stomatal density distribution $1(s d d 1)$ and too many mouths1 (tmm1). Both these mutants have at least 3-fold more stomata on their leaves per unit area than Col-WT (Table 3.2), but differ in the distribution of the stomata on the leaf surface. Overall, the increased density resulted in an eleven-fold increase in herbicidal sensitivity. This finding suggests that stomatal uptake of glyphosate may be a more important source of herbicide uptake than previously suggested. Thus the increase in stomata density by a given species (either natural or man-made) may result in increased sensitivity to this herbicide, provided all other traits remain the same.

\subsection{CONCLUSION}

An analysis of the influence of leaf phenotypic traits on glyphosate efficacy demonstrated that significant increases in trichome and stomata density increased the sensitivity of this species to glyphosate. Alternatively, increased leaf surface areas resulted in increased resistance.

\section{GENERAL CONCLUSION}

The overall aim of this project was to estimate the influence of selected traits on herbicidal efficacy, and in doing so better understand the principals for species selection in phytotoxicity testing. Analysis of herbicidal efficacy and plant traits of thirty-three different plant species showed that RGR and LAR were the traits best suited for the predication of foliar-applied herbicidal efficacy. However, when looking at the effect of changes in traits amongst members 
of the same species, it was observed that changes in trichome and stomata density had the most significant effect on sensitivity. Stepwise regression analysis showed that herbicidal efficacy may be estimated based on plant traits. Further studies on the effectiveness of the predicting ability will need to be carried out.

Although stomata was seen as one of the traits least correlated to herbicidal efficacy, results from the Arabidopsis mutants showed that when this trait is increased (either by natural or genetic manipulations), stomata infiltration may be an important source of herbicidal uptake.

Stomatal mutants, tmm1 and sdd1, and the trichome mutant bsh were the Arabidopsis mutants most sensitive to glyphosate. Alternatively, bop 1 bop 2 and glabra 1 and 3 were the most resistant. While results from Arabidopsis leaf phenotypic mutants indicate that increased trichome density results in increased sensitivity, it is important to note that the form of the trichome present may be a factor, as this may increase the retention of herbicide on the leaf surface.

Comparing the results of both projects, while it is clear that a relationship to efficacy exists with both stomata and trichome parameters, the importance of cuticular wax parameters is less definite. No clear relationship was noted between wax load and efficacy in the 33 native and crop species, but results from the Arabidopsis wax mutants (though limited in size) indicates that the wax component may be a more relevant trait. 
Since this research is limited to only foliar-applied herbicides and above ground plant traits, the introduction of new herbicides with alternative modes of application, and below ground traits may be important for future projects. 


\section{FIGURES AND TABLES}

Table 2.1- Properties of the native and crop species under consideration

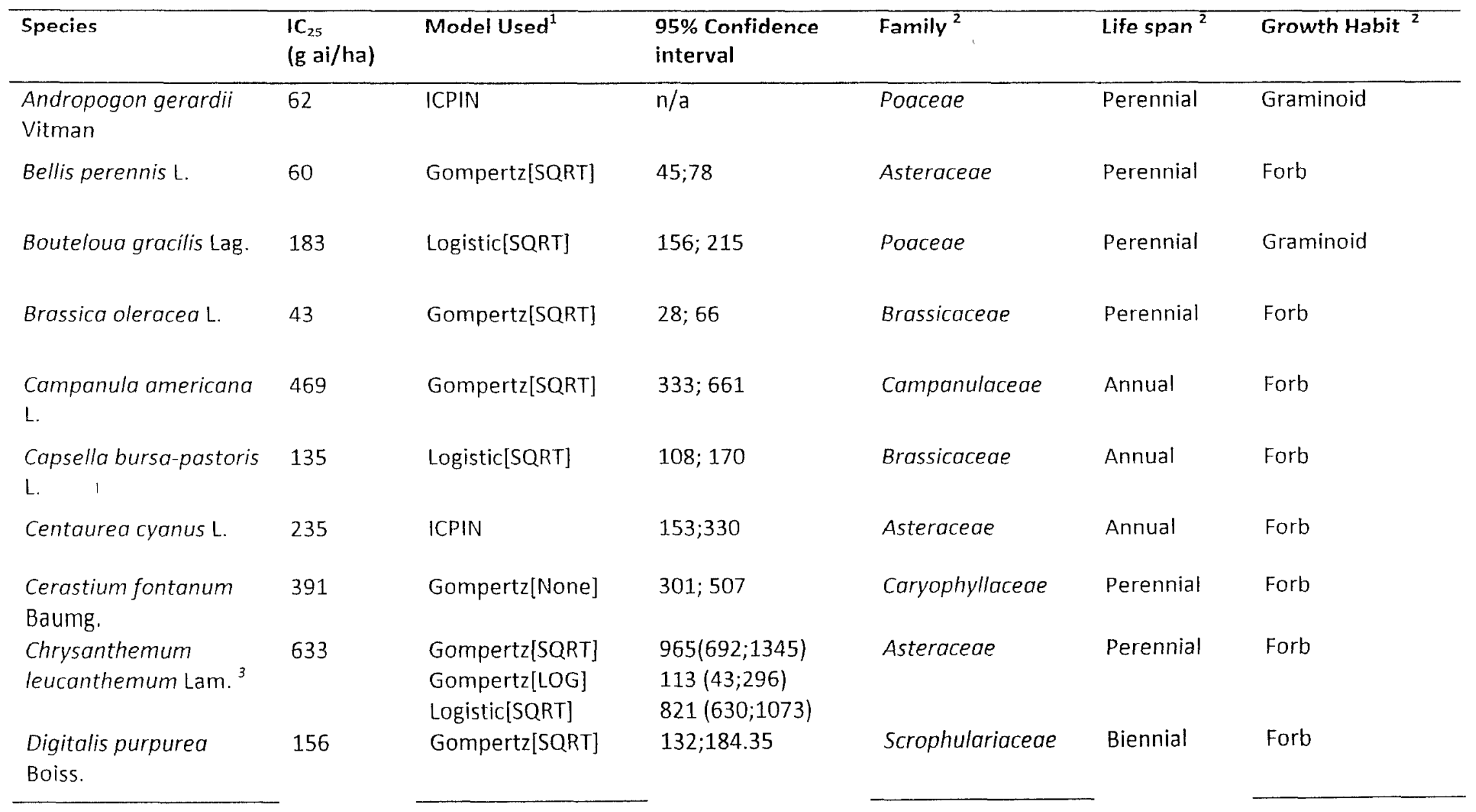




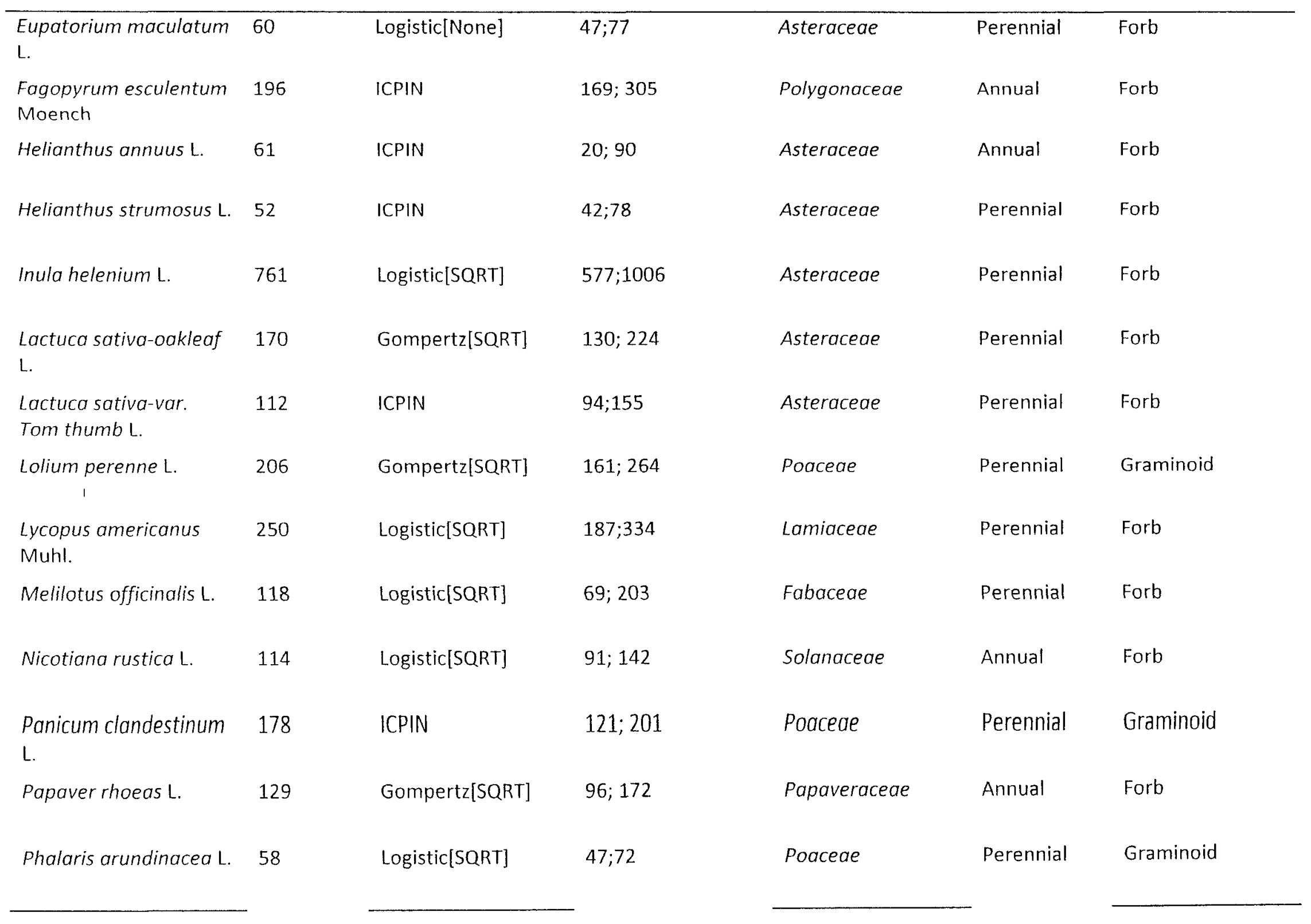




\begin{tabular}{|c|c|c|c|c|c|c|}
\hline $\begin{array}{l}\text { Phytolacca americana } \\
\text { L. }\end{array}$ & 157 & ICPIN & $117 ; 181$ & Phytolaccaceae & Perennial & Forb \\
\hline $\begin{array}{l}\text { Polygonum } \\
\text { pennsylvanicum L. }\end{array}$ & 241 & ICPIN & $193 ; 324$ & Polygonaceae & Annual & Forb \\
\hline Prunella vulgaris $\mathrm{L}$. & 215 & Gompertz[SQRT] & $150 ; 306$ & Lamiaceae & Perennial & Forb \\
\hline Rudbeckia hirta L. & 1043 & ICPIN & $402 ; 1546$ & Asteraceae & Perennial & Forb \\
\hline Solanum dulcamara $\mathrm{L}$. & 90 & Gompertz[SQRT] & $58 ; 141$ & Solanaceae & Perennial & Forb \\
\hline Solidago canadensis L. & 246 & Logistic[SQRT] & $199 ; 304$ & Asteraceae & Perennial & Forb \\
\hline Zea mays L. & 92 & ICPIN & $73 ; 111$ & Poaceae & Annual & Graminoid \\
\hline
\end{tabular}

\footnotetext{
${ }^{1}$ Transformations on the data indicated in brackets after the model used

${ }^{2}$ Data obtained from the USDA PLANTS database

${ }^{3}$ Data from another experiment (Boutin, et al 2010)
} 
Table 2.2 Range of measured variables for each experimental trait

\begin{tabular}{|c|c|c|c|c|}
\hline Variable and Corresponding units & Mean & Std Dev & Minimum & Maximum \\
\hline $1 C_{25}$ (g-al/ha) & 26012 & 25416 & 4306 & 104276 \\
\hline Relative growth rate ( $\mathrm{g} / \mathrm{g}$ day) (RGR) & 017 & 006 & 005 & 030 \\
\hline Leaf surface area $\left(\mathrm{cm}^{2}\right)$ & 1904 & 1496 & 303 & 6242 \\
\hline Leaf length $(\mathrm{cm})$ & 559 & 301 & 237 & 1424 \\
\hline Leaf width $(\mathrm{cm})$ & 171 & 085 & 013 & 392 \\
\hline Ratio leaf length to width (L/W) & 596 & 928 & 136 & 4336 \\
\hline Leaf dry weight $(\mathrm{g})$ & 008 & 008 & 001 & 043 \\
\hline Stem weight $(g)$ & 002 & 004 & 0003 & 020 \\
\hline Total plant dry weight $(\mathrm{g})$ & 010 & 011 & 001 & 063 \\
\hline Ratıo Leaf dry weight / Stem dry weight (L/S) & 487 & 302 & 156 & 1249 \\
\hline Leaf Weight Fraction (LWF) & 079 & 010 & 060 & 090 \\
\hline Stem Weight Fraction (SWF) & 021 & 009 & 007 & 039 \\
\hline Unit Leaf Rate $\left(\mathrm{g} / \mathrm{cm}^{2} /\right.$ day) (ULR) & 3948 & 5191 & 1042 & 31582 \\
\hline Leaf Area Ratio $\left(\mathrm{cm}^{2} / \mathrm{g}\right)(\mathrm{LAR})$ & 46006 & 21916 & 3496 & 110535 \\
\hline${ }^{*}$ Specific Leaf Area $\left(\mathrm{g} / \mathrm{cm}^{2}\right)(\mathrm{SLA})$ & 59526 & 29285 & 5156 & 145030 \\
\hline *Stomata length ( $\mu \mathrm{m})$ (adaxial) & 2571 & 768 & 1485 & 4994 \\
\hline *Stomata Frequency (adaxial) & 1489 & 1146 & 200 & 4817 \\
\hline Total way load $\left(\mu \mathrm{g} / \mathrm{cm}^{2}\right)$ & 519 & 640 & 024 & 3035 \\
\hline
\end{tabular}

*Adaxial layer 
Table 2.3.1: Pairwise correlation between $I C_{25}$ of glyphosate sensitive species and experimental trait parameters $(n=22)$

\begin{tabular}{|c|c|c|c|}
\hline Trait 1 & Trait 2* & $\mathrm{R}^{2}$ & Signif Prob \\
\hline \multirow{18}{*}{$\begin{array}{l}\text { Glyphdsate Inhibiting } \\
\text { Concentration } 25 \%\end{array}$} & Leaf Area Ratio (log) & -0.4877 & 0.0249 \\
\hline & Relative growth rate (Sqrt) & 0.4868 & 0.0252 \\
\hline & Leaf Weight Fraction & 0.3404 & 0.0528 \\
\hline & Unit Leaf Ratio & 0.4104 & 0.0646 \\
\hline & Stem weight & 0.3902 & 0.0803 \\
\hline & Plant dry weight & 0.3823 & 0.0872 \\
\hline & Leaf weight & 0.3708 & 0.0979 \\
\hline & Wax load & -0.3176 & 0.1607 \\
\hline & Trichome density (adaxial) & -0.315 & 0.1642 \\
\hline & Specific Leaf Area & -0.223 & 0.2123 \\
\hline & Ratio length/ width & 0.2481 & 0.2783 \\
\hline & Leaf area $(\log )$ & -0.206 & 0.3704 \\
\hline & Ratio stem weight to total plant dry weight & 0.1933 & 0.4012 \\
\hline & Leaf width (log) & -0.1874 & 0.4158 \\
\hline & Leaf length & -0.1396 & 0.5462 \\
\hline & Ratio leaf dry weight to stem dry weight & -0.1393 & 0.5471 \\
\hline & Stomata length (adaxial) & 0.1096 & 0.6363 \\
\hline & Stomata frequency (Sqrt) (adaxial) & -0.0163 & 0.9442 \\
\hline
\end{tabular}

${ }^{*}$ Only variables of glyphosate sensitive species were used. Based on the results, a resistance ratio of 5.0 was taken as cut off between sensitivity and the beginning of herbicidal resistance. 
Table 2.3.2: Pairwise correlation between $1 C_{25}$ of glyphosate resistant species and experimental trait parameters $(n=12)$

\begin{tabular}{|c|c|c|c|}
\hline Trait 1 & Trait $2^{*}$ & $\mathrm{R}^{2}$ & Signif Prob \\
\hline \multirow{18}{*}{$\begin{array}{l}\text { Glyphosate Inhibiting } \\
\text { Concentration } 25 \%\end{array}$} & Leaf Area Ratio & -0.0499 & 0.8777 \\
\hline & Relative growth rate & 0.3978 & 0.2003 \\
\hline & Leaf Weight Fraction & 0.5806 & 0.0478 \\
\hline & Unit Leaf Ratio & 0.1099 & 0.7339 \\
\hline & Stem weight & -0.3902 & 0.2098 \\
\hline & Plant dry weight & -0.1986 & 0.536 \\
\hline & Leaf weight & -0.1151 & 0.7217 \\
\hline & Wax load & 0.2110 & 0.5103 \\
\hline & Trichome density (adaxial) & 0.0468 & 0.8852 \\
\hline & Specific Leaf Area & -0.3812 & 0.2215 \\
\hline & Ratio length/ width & -0.3543 & 0.2585 \\
\hline & Leaf area & -0.2028 & 0.5273 \\
\hline & Ratio stem weight to total plant dry weight & -0.5838 & 0.0463 \\
\hline & Leaf width $(\log )$ & 0.1739 & 0.5888 \\
\hline & Leaf length & -0.1847 & 0.5655 \\
\hline & Ratio leaf dry weight to stem dry weight & 0.5833 & 0.0465 \\
\hline & Stomata length (adaxial) & 0.3608 & 0.2493 \\
\hline & Stomata frequency (adaxial) & -0.2148 & 0.5026 \\
\hline
\end{tabular}

${ }^{*}$ Only variables of glyphosate resistant species were used. Based on the results, a resistance ratio of 5.0 was taken as cut off between sensitivity and the beginning of herbicidal resistance. 
Table 2.4: Stepwise regression summary table for select models of glyphosate resistance

\begin{tabular}{|c|c|c|}
\hline Variables used & $R^{2} A d j$ & 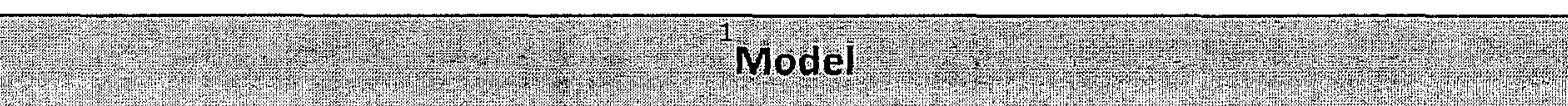 \\
\hline All species $(n=32)$ & 0.1966 & $=-103.36+23.57(\mathrm{~L} / \mathrm{S})+9.67$ (Stomata Length) \\
\hline $\begin{array}{l}{ }^{1} \text { All species above } 5.0 \\
\text { resistance profile }(n=21)\end{array}$ & 0.3985 & $\begin{array}{l}=60.89+175.47 \text { (log RGR) }+719.39 \text { (RGR) }-6.0857165 \text { (ratio Leaf weight/ stem weight) }-26.43 \text { (Trichome } \\
\text { density) }\end{array}$ \\
\hline $\begin{array}{l}{ }^{1} \text { All species below } 5.0 \\
\text { resistance profile }(n=11)\end{array}$ & 0.6808 & $\begin{array}{l}=-5055.44+11216.51 \text { (RGR) }-36.47 \text {. (Leaf area) } 6.82701921 \text { (LAR) }-10.30 \text { (Ratio Leaf length/Width) } 16.13 \\
\text { (ratio Leaf weight/ stem weight) }-42.77 \text { (Wax load) } 39.25 \text { (Stomata length) }+35.02 \text { (ULR) }\end{array}$ \\
\hline
\end{tabular}

${ }^{1}$ Both $L_{O G}$ and SQRT transformed data were used in analysis 


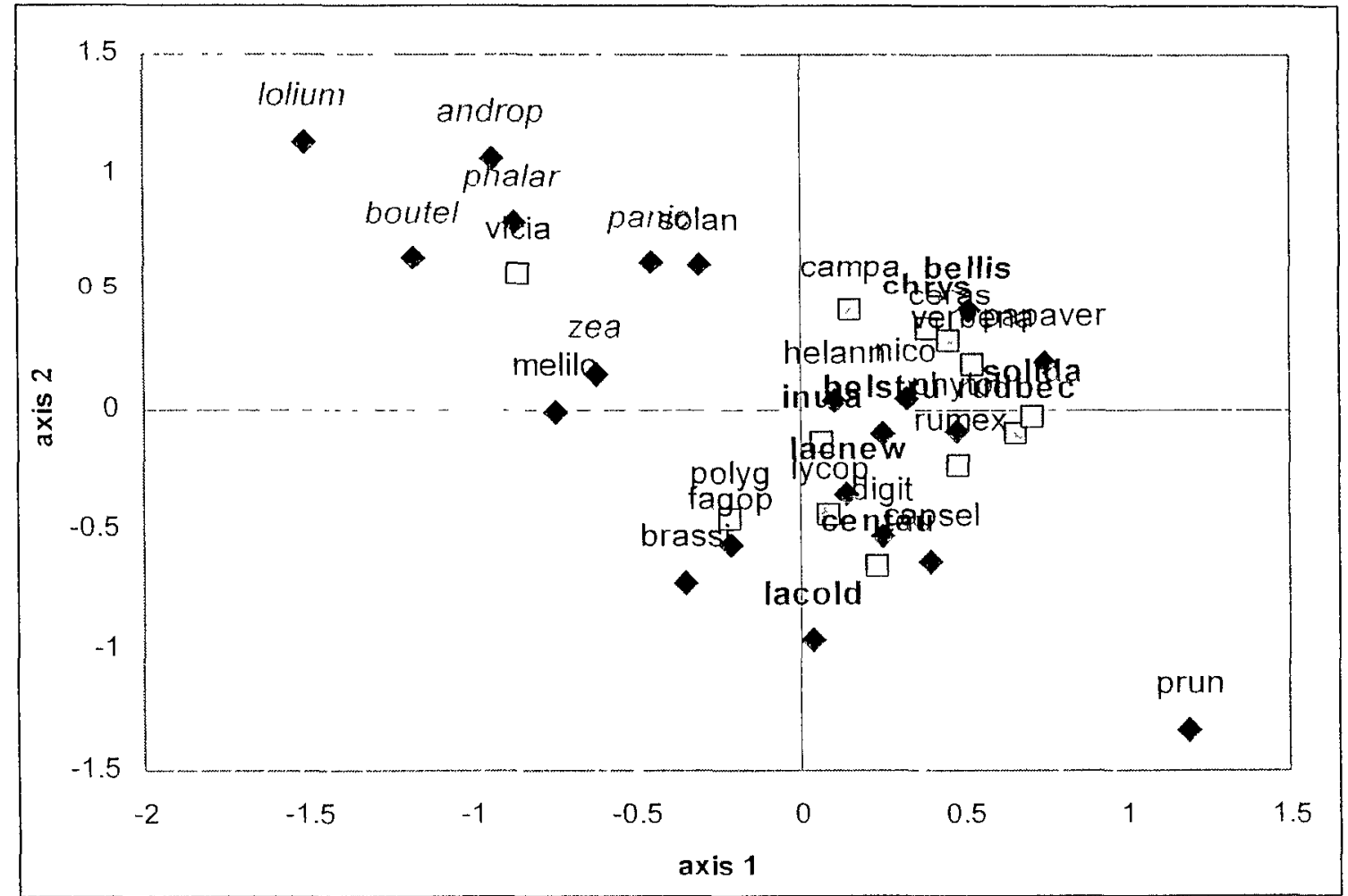

Figure 2.1: Non-metric multidimentional scaling (NMS) analysis showing the position of plant species along multiple axes according to their trait attributes. Species of the Poaceae family are shown in italics, species of the Asteraceae family in bold and the least sensitive species (with a sensitivity ratio greater then 5.0 ) are indicated with square labels. Species names can be found in Appendix 1. Please refer to appendix 1 for lant species acronyms. 
Table 3.1. Summary of Arabidopsis lines and corresponding sensitivities to glyphosate

\begin{tabular}{|c|c|c|c|c|}
\hline Mutant and ecotype & $\begin{array}{l}\text { Abbreviated } \\
\text { Wild-type or } \\
\text { Mutant Name }\end{array}$ & Phenotypic description $^{1}$ & $\begin{array}{c}\text { IC } 25 \\
\text { (gai/ha) } \\
\text { and } 95 \% \\
\text { Confidence } \\
\text { Interval }\end{array}$ & Model \\
\hline $\begin{array}{l}\text { Wild type (Landsberg } \\
\text { erecta or Ler) }\end{array}$ & Ler-WT & $\begin{array}{l}\text { Ler-WT plants are smaller than Col-WT plants. }{ }^{2} \text { Leaves of Ler } \\
\text { have greater trichome densities and a serrated margin. }\end{array}$ & $\begin{array}{c}44.10 \\
(17 ; 47)\end{array}$ & ICPIN \\
\hline $\begin{array}{l}\text { Wild type (Colombia-0 or } \\
\qquad \text { Col-0) }\end{array}$ & Col-WT & $\begin{array}{l}\text { Col-0 plants are larger than Ler plants and have shorter } \\
\text { petioles }\end{array}$ & $23(3 ; 40)$ & ICPIN \\
\hline $\begin{array}{l}\text { Blade on petiole } 1 \text { and } 2 \\
\qquad(\text { Col-o) } \\
\text { *a double mutant }\end{array}$ & bop1 bop2 & $\begin{array}{l}\text { Ectopic, lobed blades along the adaxial side of petioles of the } \\
\text { cotyledons and rosette leaves (Hepworth et al., 2005) }\end{array}$ & $\begin{array}{c}35 \\
(25 ; 47)\end{array}$ & Gompertz \\
\hline Asymmetric leaves (Col-0) & as 1 & $\begin{array}{l}\text { Asymmetric rosette leaves, leaf edges slightly curled under, } \\
\text { triangular-shaped leaves }(x u, 2008)\end{array}$ & $\begin{array}{l}61 \\
(44 ; \\
85)\end{array}$ & Gompertz \\
\hline Glabrous1 and 3 (Ler) & $g / 1-1$ & Lacks trichomes on leaves and stems. (Hauser, 2001) & $61(31 ; 130)$ & Logistic \\
\hline
\end{tabular}




\begin{tabular}{|c|c|c|c|c|}
\hline & $g / 3-1$ & $\begin{array}{l}\text { Reduced number of trichomes, which are unbranched or } \\
\text { single branched. (Koornneef, et al. 1982) }\end{array}$ & $63(25 ; 144)$ & Gompertz \\
\hline bushy (Col-0) & bsh & $\begin{array}{l}\text { Increased trichome density when compared to the } \\
\text { background wildtype (Brzeski, 1999). }\end{array}$ & $3(2 ; 5)$ & ICPIN \\
\hline $\begin{array}{l}\text { stomatal density } \\
\text { distribution-1 (Col-0) }\end{array}$ & $s d d-1$ & $\begin{array}{l}\text { Increased stomatal density on both the adaxial and abaxial } \\
\text { leaf surface. (Berger and Altmann, 2000) }\end{array}$ & $3(2 ; 5)$ & ICPIN \\
\hline too many mouths (Col-0) & $t m m-1$ & $\begin{array}{l}\text { Stomata occur in clusters, containing an even number of guard } \\
\text { cells. Lacks trichomes on leaves and stems(Yang and Sack } \\
\text { 1995; Larkin et al, 1997) }\end{array}$ & $2(1 ; 4)$ & ICPIN \\
\hline Eceriferum (col-1) & cer & Mutants which different in their epi-cuticular wax composition & $\begin{array}{l}\text { Refer to } \\
\text { Table } 3.3\end{array}$ & $\begin{array}{c}\text { Refer to Table } \\
3.3\end{array}$ \\
\hline
\end{tabular}

${ }^{1}$ Information obtained from The Arabidopsis Information Resource (TAIR). ${ }^{2}$ Information obtained from The European Arabidopsis Stock Centre (NASC). The corresponding ecotype background of each mutants is indicated in brackets: Landsberg erecta (Ler) and Columbia-0 (Col-0). 
Table 3.2: Summary of Arabidopsis mutant phenotypes and responses to glyphosate

\begin{tabular}{|c|c|c|c|c|}
\hline Trait Affected & Mutant/ecotype & ${ }^{\mathrm{a}}$ Phenotypic Trait & $\begin{array}{c}\mathrm{IC}_{25} \\
\mathrm{~g} \text {-ai/ ha } \\
\text { and } 95 \% \text { Confidence } \\
\text { Interval }\end{array}$ & $\begin{array}{c}\text { *Herbicide resistance } \\
\text { Profile }\end{array}$ \\
\hline \multirow[t]{2}{*}{1} & Col-WT & ${ }^{1} 1.17$ & 23.32 & 1.0 \\
\hline & Ler-WT & ${ }^{1} 0.42$ & 44.1 & 1.0 \\
\hline Trichome Density & g/1-1 (Ler) & 0.00 & $60.80(30.55 ; 130.22)$ & 1.4 \\
\hline \multirow[t]{2}{*}{$\left(\right.$ per $\left.\mathrm{mm}^{2}\right)$} & $g / 3-1$ (Ler) & 0.00 & $63.27(26.30 ; 143.54)$ & 1.4 \\
\hline & $\operatorname{bsh}(\mathrm{Col}-0)$ & 3.71 & 2.87 & 0.1 \\
\hline Stomata & Col-WT & ${ }^{2} 153 \pm 18$ & 23.32 & 1.0 \\
\hline \multirow{3}{*}{$\left(\right.$ per $\left.\mathrm{mm}^{2}\right)$} & $s d d-1$ (Col-0) & ${ }^{2} 582 \pm 42$ & 2.93 & 0.1 \\
\hline & $\mathrm{tmm}-1(\mathrm{Col}-0)$ & ${ }^{3} 468.3 \pm 30$ & 2.32 & 0.1 \\
\hline & Col-WT & $11.37 \pm 0.16$ & 23.32 & 1.0 \\
\hline Leaf & bop1 bop2 (Col-0) & $10.47 \pm 0.13$ & $35.24(25.18 ; 46.53)$ & 1.5 \\
\hline$\left(\mathrm{cm}^{2}\right)$ & as-1 (Col-0) & $3.01 \pm 0.14$ & $61.37(44.19 ; 85.10)$ & 2.6 \\
\hline
\end{tabular}

\footnotetext{
${ }^{*}$ Ratio of difference from respective wild type. Variables for stomata density obtained from ${ }^{1}$ (Hauser et al., 2001) ${ }^{2}(\text { Berger and Altmann, } 2000)^{3}(5 h i g e 0$ et al, 2010). ${ }^{a}$ Units of the phenotypic traits are indicated in brackets.
} 
Table 3.3: Percentage variation in leaf wax load and composition of six Landsberg erecta (Ler) eceriferum (cer) mutants

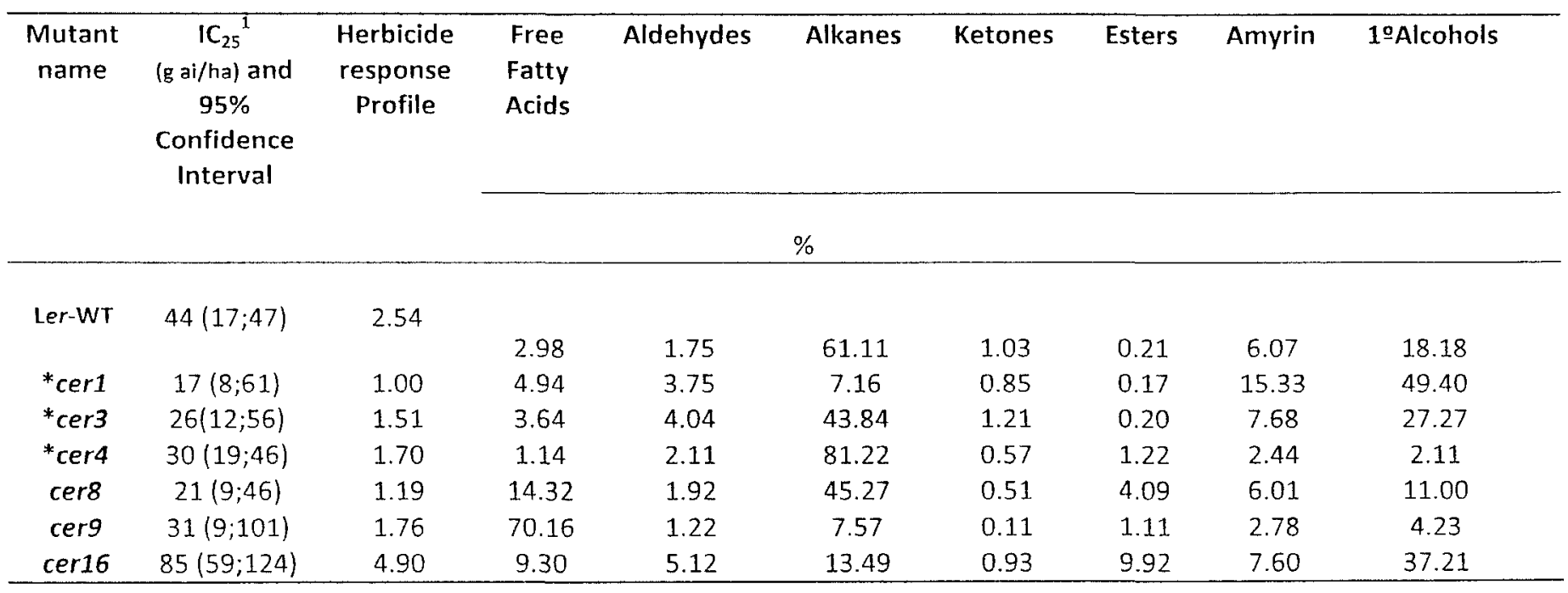

Values obtained from (Jenks et al., 1995). The actual values for the following wild type leaf wax loads are as follows Ler - $97.2 \pm 15.6$ (SE) and WS-156.1 9.2 (SE) (Jenks et al., 1995).

${ }^{1} \mathrm{C}_{25}$ values are for corresponding Ler background mutants. * Reference values are from WS ecotype

No significant relationship was noted between $\mathrm{IC}_{25}$ values and the total wax load 


\begin{tabular}{|c|c|c|c|c|c|c|c|c|c|c|c|c|c|c|c|c|}
\hline americanus & horehound & & & & & & & & & & & & & & & \\
\hline Lactuca sativa & Lettuce & lacold & 0.178 & 0.97 & 20.91 & 1.1830 & 4.40 & 0.14 & 2.07 & 0.06 & 0.100 & 0.0078 & 0.040 & 0.0028 & 0.139 & 0.011 \\
\hline Lactuca sativa & Lettuce & lacnew & 0.216 & 0.98 & 19.15 & 1.0897 & 4.34 & 0.10 & 2.15 & 0.09 & 0.118 & 0.0032 & 0.014 & 0.0028 & 0.132 & 0.006 \\
\hline Lolium perenne & Ryegrass & Iolium & 0.205 & 0.96 & 3.93 & 0.5258 & 5.67 & 0.52 & 0.13 & 0.01 & 0.011 & 0.0011 & 0.003 & 0.0003 & 0.014 & 0.001 \\
\hline $\begin{array}{l}\text { Melilotus } \\
\text { officinalis }\end{array}$ & $\begin{array}{c}\text { Yellow sweet } \\
\text { clover }\end{array}$ & melilo & 0.163 & 0.99 & 10.02 & 1.1335 & 3.31 & 0.41 & 2.30 & 0.56 & 0.031 & 0.0050 & 0.016 & 0.0022 & 0.046 & 0.007 \\
\hline $\begin{array}{c}\text { Solanum } \\
\text { dulcamara }\end{array}$ & Nightshade & solan & 0.140 & 0.95 & 10.12 & 0.5677 & 2.86 & 0.08 & 1.31 & 0.06 & 0.022 & 0.0008 & 0.008 & 0.0002 & 0.030 & 0.001 \\
\hline $\begin{array}{l}\text { Nicotiana } \\
\text { rustica }\end{array}$ & Aztec tobacco & nico & 0.169 & 0.99 & 17.11 & 2.0954 & 4.44 & 0.23 & 2.39 & 0.15 & 0.073 & 0.0099 & 0.009 & 0.0008 & 0.082 & 0.011 \\
\hline $\begin{array}{c}\text { Phalaris } \\
\text { arundinacea }\end{array}$ & Reed canary grass & phalar & 0.047 & 0.85 & 12.56 & 1.0904 & 13.76 & 0.23 & 0.61 & 0.08 & 0.017 & 0.0019 & 0.005 & 0.0010 & 0.023 & 0.003 \\
\hline Papaver rhoeas & Corn poppy & papaver & 0.262 & 0.86 & 6.24 & 1.1335 & 2.54 & 0.14 & 0.89 & 0.76 & 0.074 & 0.0021 & 0.007 & 0.0003 & 0.081 & 0.002 \\
\hline $\begin{array}{c}\text { Panicum } \\
\text { clandestinum }\end{array}$ & $\begin{array}{c}\text { Deer-tongue } \\
\text { Grass }\end{array}$ & panic & 0.163 & 0.99 & 10.37 & 0.7436 & 4.71 & 0.29 & 1.19 & 0.06 & 0.024 & 0.0018 & 0.010 & 0.0011 & 0.034 & 0.003 \\
\hline $\begin{array}{l}\text { Phytolacca } \\
\text { americana }\end{array}$ & $\begin{array}{c}\text { American } \\
\text { Pokeweed } \\
\end{array}$ & phytol & 0.172 & 0.98 & 9.51 & 0.7265 & 2.84 & 0.12 & 1.54 & 0.06 & 0.097 & 0.0068 & 0.008 & 0.0008 & 0.105 & 0.008 \\
\hline $\begin{array}{c}\text { Polygonum } \\
\text { pennsylvanicum }\end{array}$ & Pinkweed & polyg & 0.123 & 0.95 & 4.73 & 1.2734 & 2.64 & 0.21 & 1.95 & 0.09 & 0.058 & 0.0079 & 0.020 & 0.0026 & 0.078 & 0.010 \\
\hline $\begin{array}{l}\text { Prunella } \\
\text { vulgaris } \\
\end{array}$ & $\begin{array}{c}\text { Common Self- } \\
\text { heal }\end{array}$ & prun & 0.232 & 1.00 & 11.00 & 2.2096 & 5.86 & 0.19 & 2.70 & 0.24 & 0.427 & 0.0264 & 0.203 & 0.0997 & 0.629 & 0.126 \\
\hline Rumex crispus & Curly dock & rumex & 0.231 & 1.00 & 4.70 & 0.3286 & 5.56 & 0.21 & 2.09 & 0.25 & 0.068 & 0.0058 & 0.011 & 0.0005 & 0.079 & 0.006 \\
\hline Rudbeckia hirta & - Black eyed Susan & rudbec & 0.205 & 0.99 & 21.49 & 1.8246 & 2.37 & 0.77 & 1.06 & 0.10 & 0.111 & 0.0128 & 0.011 & 0.0013 & 0.122 & 0.014 \\
\hline $\begin{array}{c}\text { Solidago } \\
\text { canadensis }\end{array}$ & $\begin{array}{c}\text { Canada } \\
\text { goldenrod }\end{array}$ & solida & 0.218 & 0.99 & 12.05 & 1.0250 & 6.37 & 0.13 & 1.63 & 0.09 & 0.085 & 0.0039 & 0.014 & 0.0015 & 0.099 & 0.005 \\
\hline Vicia americana & Blue Vervain & vicia & 0.127 & 0.98 & 3.73 & 0.5264 & 3.74 & 0.14 & 0.45 & 0.32 & 0.010 & 0.0013 & 0.005 & 0.0007 & 0.015 & 0.002 \\
\hline $\begin{array}{c}\text { Verbena } \\
\text { hastata } \\
\end{array}$ & Swamp verbena & verbena & 0.090 & 1.00 & 31.70 & 2.9578 & 4.61 & 0.61 & 1.51 & 0.46 & 0.083 & 0.0077 & 0.012 & 0.0020 & 0.095 & 0.010 \\
\hline $\begin{array}{l}\text { Helianthus } \\
\text { strumosus }\end{array}$ & $\begin{array}{l}\text { Sunflower- } \\
\text { Teddybear }\end{array}$ & helstru & 0.147 & 0.96 & 21.21 & 1.8089 & 4.89 & 0.22 & 1.50 & 0.13 & 0.074 & 0.0068 & 0.019 & 0.0012 & 0.093 & 0.008 \\
\hline
\end{tabular}


Appendix 1.2: Wax, trichome and stomata characteristics of plant species used in this study

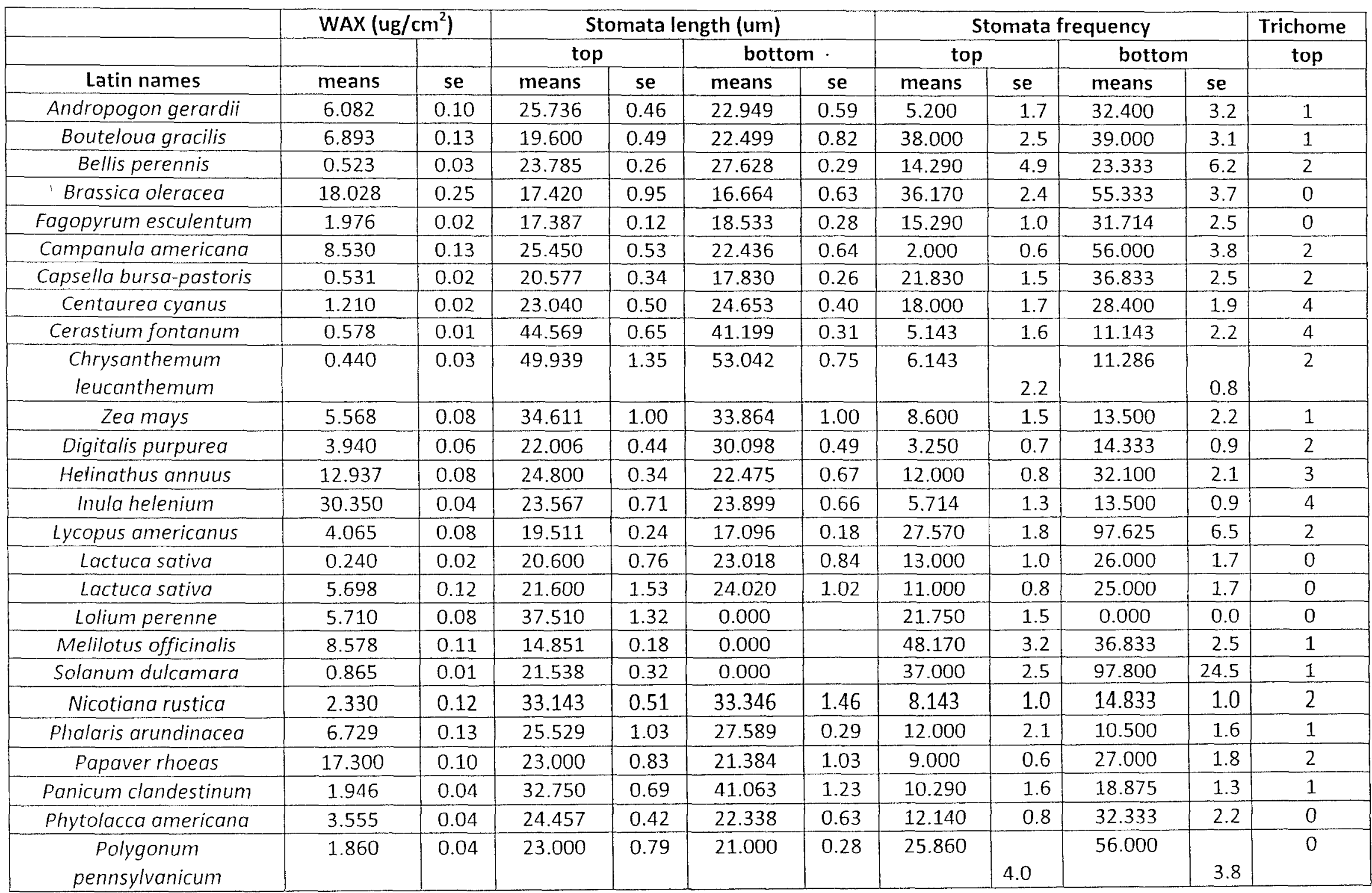




\begin{tabular}{|c|c|c|c|c|c|c|c|c|c|c|c|}
\hline Prunella vulgaris & 1.276 & 0.13 & 26.735 & 0.58 & 24.949 & 0.48 & 6.875 & 3.9 & 32.333 & 2.1 & 2 \\
\hline Rumex crispus & 1.173 & 0.14 & 34.300 & 0.94 & 33.506 & 0.70 & 8.571 & 2.3 & 16.143 & 1.9 & 0 \\
\hline Rudbeckia hirta & 1.022 & 0.03 & 27.685 & 0.31 & 33.866 & 0.37 & 19.000 & 4.3 & 28.000 & 2.9 & 3 \\
\hline Solidago canadensis & 1.251 & 0.03 & 19.586 & 0.42 & 24.739 & 0.68 & 3.500 & 1.8 & 20.000 & 1.5 & 2 \\
\hline Vicia americana & 4.776 & 0.10 & 20.171 & 0.49 & 23.398 & 0.67 & 12.000 & 1.8 & 16.000 & 1.1 & 0 \\
\hline Verbena hastata & 0.860 & 0.01 & 23.000 & 0.20 & 21.000 & 0.32 & 9.000 & 3.4 & 106.000 & 16.5 & 3 \\
\hline Helianthus strumosus & 4.292 & 0.03 & 27.000 & 0.54 & 20.020 & 0.85 & 4.800 & 1.7 & no data & & 3 \\
\hline
\end{tabular}




\section{REFERENCES}

Ahmadi, M. S., Haderlie, L. C. and Wicks, G. A. 1980. Effect of growth stage and water stress on barnyard-grass (Echinochloa crus-galli) control and on glyphosate absorption and translocation. Weed Sci. 28:277-282

Alonso-Blanco, C., and Koornneef, M. 2000. Naturally occurring variation in Arabidopsis: an underexploited resource for plant genetics. Trends Plant Sci. 5 22-29.

Baird, D.J. and Van den Brink, P.J. 2007. Using biological traits to predict species response to toxic substances. Ecotoxicology and Environmental Safety. 67: 296-301

Baker, E.A. 1980. Effect of cuticular components on foliar penetration. Pesticide Science 11, 367-370

Baylis, A. D. 2000. Why glyphosate is a global herbicide: strengths, weaknesses and prospects. Pest Management Science Special Issue: Glyphosate Special Issue.56: 299-308

Belles, D., Shaner, D., Westra, P., Brunk, G. 2006. Comparison of efficacy, absorption and translocation of three glyphosate formulations on velvetleaf (Abutilon theophrasti).Pest Manag Sci. 62(12):1177-81.

Benzing, D. H., and Burt, K. M. 1970. Foliar permeability among twenty species of the Bromeliaceae. Bull. Torrey Bot. Club 97:269-279.

Berger, D and Altmann, T. 2000. A subtilisin-like serine protease involved in the regulation of stomatal density and distribution in Arabıdopsis thaliana. Genes Dev. 14: 1119-1131

Boutin, C and Jobin, B. 1998. Intensity of Agricultural Practices and Effects on Adjacent Habitats. Ecological Applications. 8: 544-557 
Boutin, C. and Rogers, C.A. 2000. Pattern of sensitivity of plant species to various herbicides-An analysis with two databases. Ecotoxicology 9:255-271.

Brotherton, J. E., Jeschke, M. R., Tranel, P. J., and Widholm, J. M. 2007. Identification of Arabidopsis thaliana variants with differential glyphosate responses. Journal of Plant Physiology 164: 13371345.

Brzeski, J., Podstolsk,i W., Olczak, K., Jerzmanowski, A.1999. Identification and analysis of the Arabidopsis thaliana BSH gene, a member of the SNF5 gene family. Nucleic Acids Res 27: 23932399

Chachalis, D., Reddy, K. N., and Eimore, C. D.,2001a. Characterization of leaf surface, wax composition, and control of redvine and trumpetcreeper with glyphosate. Weed Sci. 49:156-163.

Chachalis, D., Reddy, K. N., Elmore, C. D. and Steele, M. L. 2001b. Herbicide efficacy, leaf structure, and spray droplet contact angle among Ipomoea species and smallflower morningglory. Weed Sci. $49: 628-634$.

Conacher, J. and Conacher, A., 1986. Herbicides in Agriculture: Minimum Tillage, Science and Society. GEOWEST No. 22, University of Western Australia, Nedlands, WA, $169 \mathrm{pp}$

Edmund, R. M., Jr. and A. C. York. 1987. Factors affecting postemergence control of sicklepod (Cassia obtusifolia) with imazaquin and DPX-F6025; spray volume, growth stage, and soil-applied alachlor and vernolate. Weed Sci. 35:216-223.

Environment Canada. 2005. Guidance document on application and interpretation of single-species tests in environmental toxicology. Report EPS 1/RM/46. Methods Development and Application Section, Environmental Technology Centre, Ottawa, ON. 
Gonzlez-Torralva, F., Cruz-Hipolito, H., Bastida, F., Mlleder, N., Smeda, R. J., and De Prado R. 2010. Differential Susceptibility to Glyphosate among the Conyza Weed Species in Spain. Journal of Agricultural and Food Chemistry. 58: 4361-4366

Hauser, M.T., Harr, B., Schlötterer, C. 2001. Trichome Distribution in Arabidopsis thaliana and its Close Relative Arabidopsis lyrata: Molecular Analysis of the Candidate Gene GLABROUS1. Mol. Biol. Evol. 18:1754-63.

Hepworth, S.R., Zhang, Y., McKim. S., Li, X., Haughn, G.W. 2005 BLADE-ONPETIOLE- dependent signaling controls leaf and floral patterning in Arabidopsis. Plant Cell. 17:1434-1448.

Hess, F. D., D. E. Bayer, and R. H. Falk. 1974. Herbicide dispersal patterns: I. As a function of leaf surface. Weed Sci. 22: 394-401.

Hess, F.D. and Falk, R.H. 1990. Herbicide deposition on leaf surfaces. Weed Science, v.38, p.280-288

Hoss, N.E., Al-Khatib, K., Peterson, D. E., and Loughin, T. M. 2003. Efficacy of glyphosate, glufosinate, and imazethapyr on selected weed species. Weed Science 51:1, 110-117

Huangfu, C.H., Song, X.L., Qiang, S., Zhang H.J. 2007. Response of wild Brassica juncea populations to glyphosate. Pest Manag Sci 63:1133-1140.

Hull, H. M., Davis, D. G., and Stolzenberg, G. E. 1982. Actions of adjuvant on plant surface. Pages 26-67 in Adjuvants for Herbicides. Lawrence, KS: Weed Science Society of America.

Hunt, R., Causton, D. R., Shipley, B., Askew, P.2002. A modern tool for classical plant growth analysis. Ann. Bot., 90, 485-488 
Jenks, M.A., Tuttle, H.A., Eigenbrode, S.D., Feldman, K.A. 1995. Leaf epicuticular waxes of the eceriferum mutants in Arabidopsis. Plant Physiol, 108:369-77

Kolattukudy, P.E. 1980. Biopolyester membranes of plants - Cutin and Suberin. Science. 208: 990-1000.

Larkin, J.C., Marks, M.D., Nadeau, J., Sack, F .1997. Epidermal cell fate and patterning in leaves. - Plant Cell 9: 1109-1120,

Larkin, J. C., Walker, J. D., Bolognesi-Winfield A. C., John C. Gray, and A. R. Walker. 1999. Allele-Specific Interactions Between ttg and gl1 During Trichome Development in Arabidopsis thaliana. Genetics. 151: 1591-1604

Mahna, E.G., and Helmeckea, K. 1979. Effects of herbicide treatment on the structure and functioning of agro-ecosystems II. Structural changes in the plant community after the application of herbicides over several years. Agro-Ecosystems. 5: 159-179

Mayeux, H.S., and Jordan, W. R. 1980. Epicuticular wax content and herbicide penetration of goldenweed leaves. Proc. So. Weed Sci. Soc. 33:289.

McCune, B., Grace. J.B. 2002. Analysis of Ecological Communities. MjM Software Design, Gleneden Beach, Oregon

McGee, W.G., Berges, H., and Beaton, D. 2010. Survey of Pesticide Use in Ontario, 2008 Estimates of Pesticides Used on Field Crops, Fruit and Vegetable Crops, and Other Agricultural Crops. http://www.omafra.gov.on.ca/english/crops/facts/pesticide-use.htm. Accessed: November 1, 2010.

Meinke, D. W., Cherry, J.M., Dean, C., Rounsley, S.D. and Koornneef, M.1998. Arabidopsis thaliana: a model plant for genome analysis. Science, $282,679-682$ 
Muzik, T. J. 1976. Influence of environmental factors on toxicity to plants. In Herbicides, Physiology, Biochemistry, Ecology, ed L.J. Audus. Academic Press, London, pp 203-247

Norberg-King, T.J. 1993. A linear interpolation method for sublethal toxicity: the inhibition concentration (ICp) approach (version 2.0). Technical Report 03-93. U. S. Environmental Protection Agency, Environmental Research Laboratory, Duluth, MN.

OECD Guidelines for the Testing of Chemicals (OECD) (1984). 208: Terrestrial Plants, Growth Test, Organisation for Economic Co-operation and Development, Paris.

Organisation for Economic Co-operation and Development (OECD) (2006) Terrestrial Plants, Growth Test no. 208 and no. 227.OECD Guidelines for Testing Chemicals, Paris, France

Poorter, H. and de Jong, R. 1999. A comparison of specific leaf area, chemical composition and leaf construction costs of field plants from 15 habitats differing in productivity. New Phytol. 143: 163-176.

Poorter, H., and Remkes, C. 1990. Leaf area ratio and net assimilation rate of 24 wild species differing in relative growth rate. Oecologia. 83: 553-559

Pratley, J., Urwin, N., Stanton, R., Baines P., Broster, J. , Cullis, K., Schafer, D., Bohn J. and Krueger, R. 1999. Resistance to glyphosate in Lolium rigidum. I. Bioevaluation. Weed Sci. 47:405-411

Riemens, M.M, Dueck, T., Kempenaar, C. 2008. Predicting sublethal effects of herbicides on terrestrial non-crop plant species in the field from greenhouse data. Environ Pollut 155:141-149

Riethmuller-Haage, I., Bastiaans, L., Kempenaar, C., Smutny, V., and Kropff, M.J. 2007. Are pre-spraying growing conditions a major determinant of herbicide efficiency? Weed Res 47: 415-424 
Santier, S and Chamel A 1992 Penetration of glyphosate and diuron into and through isolated plant cuticles Weed Res 32 337-347

Shaner, D 2006 An overview of glyphosate mode of action Why is it such a great herbicide NCWSS Proceedings 6194

Sulivan, T P, and Sullivan, D S 2003 Vegetation management and ecosystem disturbance impact of glyphosate herbicide on plant and anımal diversity in terrestrial systems Environ Rev 11 37-59

Tholen, D.J.H., Voesenek, LA.C.J, Poorter, H 2004 Ethylene insensitivity does not increase leaf area or relative growth rate in Arabıdopsis, Nicotiana tabacum, and Petunia x hybrida Plant Physıol 134 $1803-1812$

US Environmental Protection Agency 1996 Ecological effects test guidelines Terrestrial plant toxicityVegetatıve vigor OPPTS 8504150 and 4250 EPA 712-C-96-163 Washington, DC

Uzun, S 2004 Quantıtative effects of plantıng tıme on vegetatıve growth of broccolı(Brassıca oleracea Var Itaiıca) Pak J Bot, 36 769-777

Wang, CJ, and LıU, ZQ 2007 Folıar uptake of pestıcıdes, present status and future challenge, Pest Biochem Physiol 87 1-8

White, $A L$, and Boutin, C 2007 Herbicidal effects on non-target vegetation investigating the limitations of current pesticide registratıon guidelınes Environ Toxicol Chem 26.2634-2643

Wilkınson, RE 1980 Ecotypıc variatıon of Tamarix pentandra epıcutıcular wax and possible relatıonshıp with herbicide sensitivity Weed ScI 28 110-113

Wilkınson, RE, and Mayeux HS 1987 Compositıon of epıcutıcular wax on isocoma leaves Bot Gaz, $148 \quad 12-16$ 
Wyrill, J. B. and Burnside, O. C. 1976. Absorption, translocation and metabolism of 2,4-D and glyphosate in common milkweed and hemp dogbane. Weed Sci. 24: 557566.

Xu, B., Li, Z., Zhu, Y., Wang, H., Ma, H., Dong, A., and Huang, H. 2008. Arabidopsis genes AS1, AS2, and JAG negatively regulate boundary-specifying genes to promote sepal and petal development. Plant Physiol. 146:566-575

Yang, M., and Sack, F.D. (1995). The too many mouths and four lips mutations affect stomatal production in Arabidopsis. Plant Cell 7: 2227-2239 